\title{
Ancient and modern anastomosing rivers: insights from sedimentological and geomorphological case studies of the Triassic, Neogene and Holocene of Poland
}

\author{
Artur KĘDZIOR ${ }^{1}$, Marek WIDERA ${ }^{2, *}$ and Tomasz ZIELIŃSKI \\ 1 Polish Academy of Sciences, Institute of Geological Sciences, Twarda 51/55, 00-818 Warszawa, Poland \\ 2 Adam Mickiewicz University, Institute of Geology, Krygowskiego 12, 61-680 Poznań, Poland
}

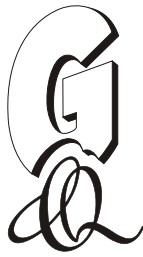

Kędzior, A., Widera, M., Zieliński, T., 2021. Ancient and modern anastomosing rivers: insights from sedimentological and geomorphological case studies of the Triassic, Neogene and Holocene of Poland. Geological Quarterly, 65: 54, doi: $10.7306 / \mathrm{gq} .1623$

Associate Editor: Anna Wysocka

We review the three regional anastomosing fluvial systems, both ancient and modern. The dinosaur-bearing upper Triassic succession in Krasiejów (S Poland) is composed of siltstones and claystones that are divided into three facies associations. One of the fluvial associations is characterized by features typical of a low-energy anastomosing river system in a tropical semiarid climate, interpreted as the result of accumulation in deep, wide and low-sinuosity palaeochannels with pronounced vertical accretion. Deposition from suspension predominated in flows of very low stream power. The upper Neogene muddy succession in a tectonically active area (Kleczew Graben, central Poland) includes a great number of fluvial palaeochannels filled with sand and/or mud. These ribbon-shaped fluvial bodies are deep and wide, and represent channels showing very limited lateral migration. They were filled mostly under low-energy conditions, and their mapped course shows an "anabranching" pattern in plan view. The palaeochannels are transitional from sand- to mud-dominated. The Holocene upper Narew River (NE Poland) represents a modern anastomosing fluvial system. The interconnected channels form an anabranching pattern. The channels are straight to slightly sinuous, relatively deep and wide. Interchannel, low-lying "islands" are covered by peat-forming plants. Despite the low stream power, in-channel deposition is dominated by sand transported as bedload. The channel banks are stabilised by vegetation, which effectively prevents their lateral migration.

Key words: fluvial environment, facies analysis, river type, tectonics, climate, Poland.

\section{INTRODUCTION}

\section{TERMINOLOGY}

In this review paper, the term "anastomosing river" is used in the sense originally proposed by Smith and Smith (1980: 157). These researchers defined this river type as "an interconnected network of low-gradient, relatively deep and narrow, straight to sinuous channels with stable banks of fine-grained sediment (silt/clay) and vegetation."

Originally, rivers were divided into straight, meandering, and braided types in the classical classification of Leopold and Wolman (1957). Most likely, Schumm (1968: 1580) was the first to describe a pattern of river channels dividing around relatively large and stable islands as "anastomosing", but not braided. Nevertheless, researchers are still debating the classification of multi-channel rivers, despite at least 40 years of modern studies

\footnotetext{
* Corresponding author, e-mail: widera@amu.edu.pl
}

Received: August 17, 2021; accepted: November 2, 2021; first published online: November 23, 2021 beginning with the pioneering paper of Smith and Smith (1980). Anastomosing rivers generally constitute a subset in the broad category of so-called "anabranching" rivers (Nanson and Knighton, 1996). The terms "anastomosing" and "anabranching" are sometimes used alternatively, which can be confusing because, for example, both braided and anastomosing river types may be anabranching. Therefore, the term "anastomosing" is limited in this paper to that group of "anabranching" rivers which are low-energy with organic or fine-grained floodplains (Nanson, 2013).

The etymology of the words "anastomosing" and "anabranching" (i.e., their origin and historic usage) was discussed in detail by Carling et al. (2014). According to them, "anastomosing" originally meant an opening, outlet or connection of one water body with another, while "anabranching" referred to "anastomosing branches". Thus, these two terms are grammatically synonymous (Carling et al., 2014). In addition, both terms are commonly used in the literature to describe multi-channel patterns of apparently similar planform. Therefore, the use of the terms "anastomosing" and "anabranching" has been extensively discussed (Nadon, 1994; Schumm et al., 1996; Makaske, 1998, 2001; Tooth, 2000; Twidale, 2004; North et al., 2007; Davies and Gibling, 2013; Phillips, 2014). 


\section{POLISH ANASTOMOSING RIVERS AND RESEARCH OBJECTIVES}

Relatively good exposures of fluvial deposits of late Triassic and late Neogene ages made it possible to conduct detail sedimentological studies. In both cases, the shape of the river channels could be determined and a precise facies analysis of their infills was made. So far, Polish anastomoses of Triassic age have been examined in detail three times (Bilan, 1975; Gruszka and Zieliński, 2008; Jewuła et al., 2019), while there have been several studies of those of Neogene age (Widera, 2012, 2013; Widera et al., 2017, 2019; Maciaszek et al., 2019, 2020; Zieliński and Widera, 2020). Due to their easy accessibility, modern (Holocene) anastomosing rivers have been investigated most comprehensively, that is, sedimentologically, botanically, and hydrologically (Gradziński et al., 2000, 2003a, b).

The present article brings together results of regional studies on Polish anastomosing rivers, achieved over the last 20 years by the authors, who participated in nearly all of these sedimentological and geomorphological studies, knowing in detail their advantages and limitations both during data collection in the field, and during their interpretation. Therefore, the study aims to: (i) review the current state of knowledge on three anastomosing river systems in Poland, which are of different ages and formed in different tectonic and climatic conditions; (ii) describe and interpret both channel and overbank facies of these anastomosing river systems; (iii) note the most closely related global, modern analogues of these anastomosing fluvial systems in the context of factors controlling their deposition; and (iv) make intercomparisons of these systems, taking into account their major features and/or parameters.

\section{GEOLOGICAL AND PALAEOGEOGRAPHIC SETTING OF POLISH ANASTOMOSING RIVERS}

The most important geological information concerning the stratigraphic position of the fluvial successions investigated are presented. Their lithostratigraphy and approximate chronostratigraphic levels are described, which helps estimate the role of the factors (tectonic and/or climatic) influencing the development of these anastomosing river systems. Their deposits outcrop in the areas of Krasiejów, Konin, and the upper Narew River (Fig. 1). Simplified palaeogeographic maps show the areas where deposition takes/took place in the Holocene, late Neogene and late Triassic, respectively (Fig. 1B-D).

\section{UPPER TRIASSIC DEPOSITS}

The sedimentary succession, exposed at Krasiejów which is $\sim 10 \mathrm{~km}$ east of the town of Opole in S Poland (Fig. 1B), encompasses $15-20 \mathrm{~m}$ of muddy deposits of late Triassic age. A more precise determination of the age of these strata is still under discussion, but they appear to be Norian succession (e.g., Szulc and Racki, 2015; Szulc et al., 2015; Jewuła et al., 2019). Lithostratigraphically, the mudstones belong to the Patoka Member of the Grabowa Formation (Fig. 2A).

\section{UPPER NEOGENE DEPOSITS}

Muddy deposits containing clearly visible channel forms are mostly exposed in the opencast sites belonging to the Konin Lignite Mine, 20-25 km north of the city of Konin in central Poland (Fig. 1B). The lignite deposits occur in relatively shallow fault-bounded tectonic grabens, such as the Kleczew Graben (Widera, 2016b, 2021; Widera et al., 2021a). From the lignite mining, sedimentary sections several tens of metres high were available for field research, including those of late Neogene age. The fine-grained deposits studied (overbank muds, in-channel fine sands and muds) lie between the 1st Mid-Polish Lignite Seam and glaciogenic Quaternary deposits. Hence, their depositional age is constrained to an interval from the late mid-Miocene to the earliest Pliocene (Fig. 2B).

Lithostratigraphically, the muddy succession investigated is termed the Wielkopolska Member, constituting the upper part of the Poznan Formation, which is the youngest Neogene lithostratigraphic unit in central Poland (Piwocki and Ziembińska-Tworzydło, 1997; Widera, 2007, 2021). Lithologically diverse river channel-fills (sandy, sandy-muddy, muddy) are incised into the surrounding muds and locally even into the underlying lignite seam (Fig. 2B).

\section{HOLOCENE DEPOSITS}

The segment studied of the Narew River, which is a northeastern tributary of the Wisła River (the largest Polish river), covers its upper course. This area is located $\sim 10-20 \mathrm{~km}$ south-west and west of the city of Białystok in NE Poland (Fig. 1B). The upper Narew River occupies a flat-bottomed valley, which is made up of late Pleistocene and Holocene deposits (Fig. 2C).

The modern sediments studied of the upper Narew River are, underlain and surrounded by Pleistocene glaciogenic and fluvioglacial, and Holocene organic-mineral deposits. The glaciogenic tills, gravels, sands, and muds belong to the uppermost beds of the Saalian - the Mid-Polish Glaciation - whereas the fluvioglacial gravels and sands represent the Weichselian the North-Polish Glaciation (Lindner and Astapowa, 2000). The channel sands, overbank peats, and sandy peats are of Holocene age as shown by radiocarbon dating. The oldest ${ }^{14} \mathrm{C}$ dates are $\sim 10,000$ BP (Fig. 2C), but most of them are between 3200 and 1340 BP (Gradziński et al., 2000, 2003a, b).

\section{MATERIALS AND METHODS}

Our fieldwork took place in 1998-2000 (Narew River area), 2003-2004 (Krasiejów area), and 2006-2018 (Konin area). The results obtained were supplemented in 2019-2021 by new field observations and photographs. Cumulatively, these long-term studies included: identification and description of sedimentary facies, measurements of palaeocurrent directions, logging of sedimentary sections, geological mapping and sediment sampling (including lacquer peel samples), as well as taking photographs both from the ground and from the air.

The methods used differed depending on the sediment type, availability, and the quality of the exposures. For example, all data from the Krasiejów area came exclusively from exposure. In the Konin area, in addition to data from lignite opencasts (Jóźwin IIB and Kazimierz North), information from $>700$ deep boreholes (up to >80 m) were also used to identify sandy and sandy-muddy palaeochannels within the mud-rich successions. Over 200 shallow boreholes (up to 5-6 m deep) were drilled manually in the Narew River area in both channel and interchannel deposits, to collect sediment cores and/or samples for further studies. Two hundred eleven (30 Krasiejów, 116 - Konin, 65 - Narew) samples of clastic deposits were taken from these areas for sieve and areometric analysis. Additionally, 40 samples of organic deposits (peat and sandy peat) from the Narew River area were collected for radiocarbon dating. The mode of deposition from saltation and graded/uniform/pelagic suspension was determined according to the traditional method defined by Passega (1977). 


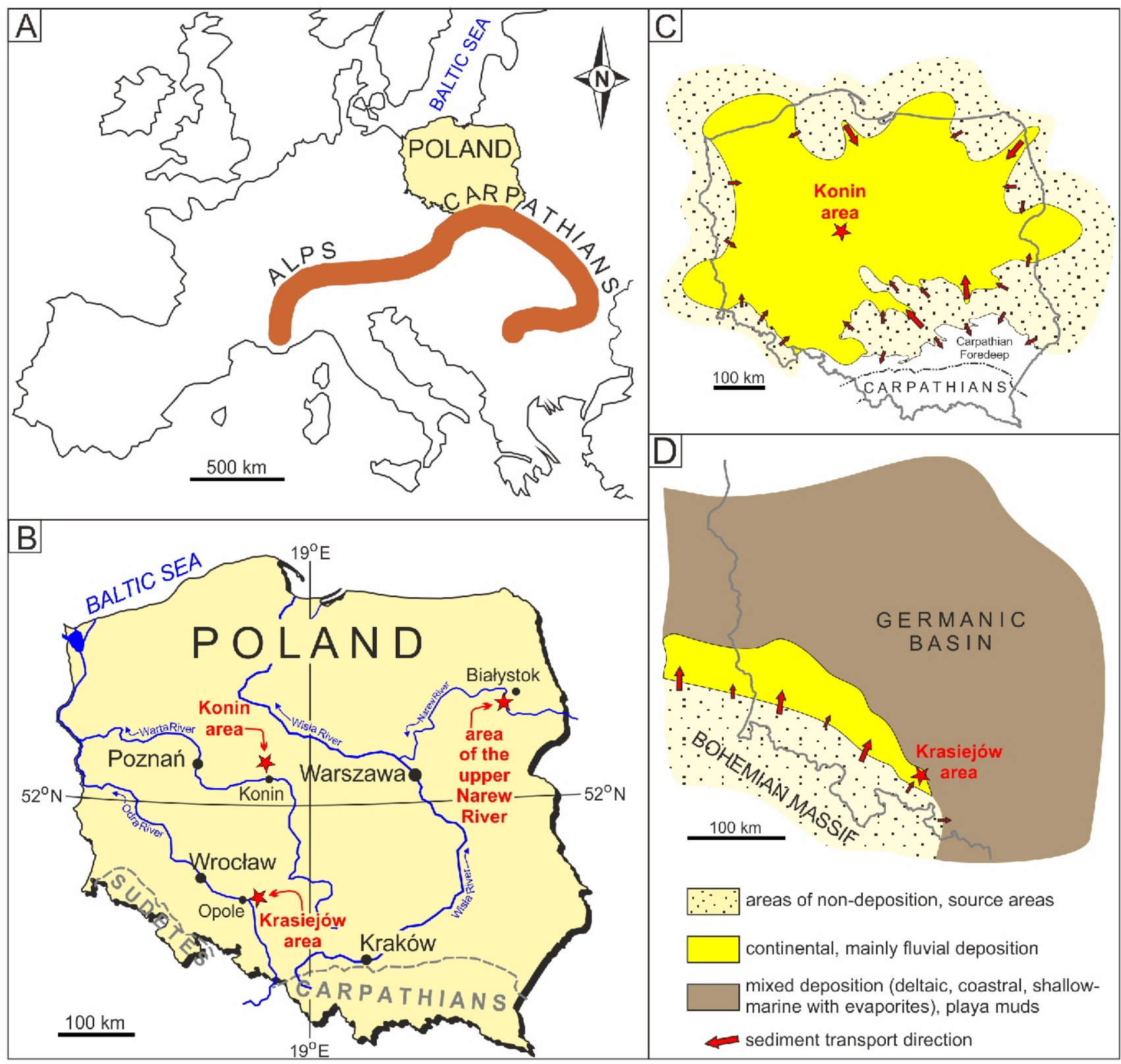

Fig. 1. Location and palaeogeographic maps of the study areas

A - Poland within the setting of Europe; B - approximate location of the areas of Krasiejów, Konin and the upper Narew River with present-day palaeogeography of the Polish territory including the upper Narew River area; C - reconstructed late Neogene palaeogeography of the Konin area (modified from Czapowski and Kasiński, 2002; Widera, 2013); D - reconstructed late Triassic palaeogeography of the Krasiejów area (modified from Ziegler, 1982; McKie and Williams, 2009)

The standard classification of siliciclastic rocks is generally used in this paper (Shepard, 1954). To shorten the description of facies in the figures, most well-known textural and structural codes are applied after Miall (1977), while the textural code for silt (T) is after Ghibaudo (1992). However, codes for mud (M) and clay $(Y)$, as well as codes for lenticular/nodular lamination (n) are used in the sense strictly defined by Widera et al. (2019). Thus, mud is a mixture of sand-silt-clay fractions in an amount of at least $20 \mathrm{wt} . \%$ each, corresponding to the middle field in the textural classification scheme for siliciclastic deposits (Shepard 1954). The letter $Y$ is proposed for clay because the letter $C$ means coal or carbonaceous. Likewise, the letter I cannot be used for lenticular (nodular) laminations, which denotes low-angle cross-stratification in Miall's (1977) original codification of facies (Table 1).
Geological mapping (Krasiejów and Konin areas) and direct width and thickness (depth) measurements (Narew River area) allowed calculation of the width/thickness $(w / t)$ ratios of the palaeochannel bodies. Furthermore, $>200$ measurements of dip and dip azimuth of cross-laminae and azimuths of palaeochannels, as well as measurements of present-day water flow directions (Narew River area) were made in the field. These activities allowed the reconstruction of a fragment of the palaeochannel pattern of the late Neogene river system in the Konin area and of the Triassic one in Krasiejów. The following parameters were calculated using well-known palaeohydraulic formulae for low-energy rivers: original height of bedforms, depth of palaeoflows, flow velocity and flow power (Rees, 1966; Bridge and Jarvis, 1982; Leclair and Bridge, 2001), and palaeochannel sinuosity (Reddy and Prasad, 1988). 
A

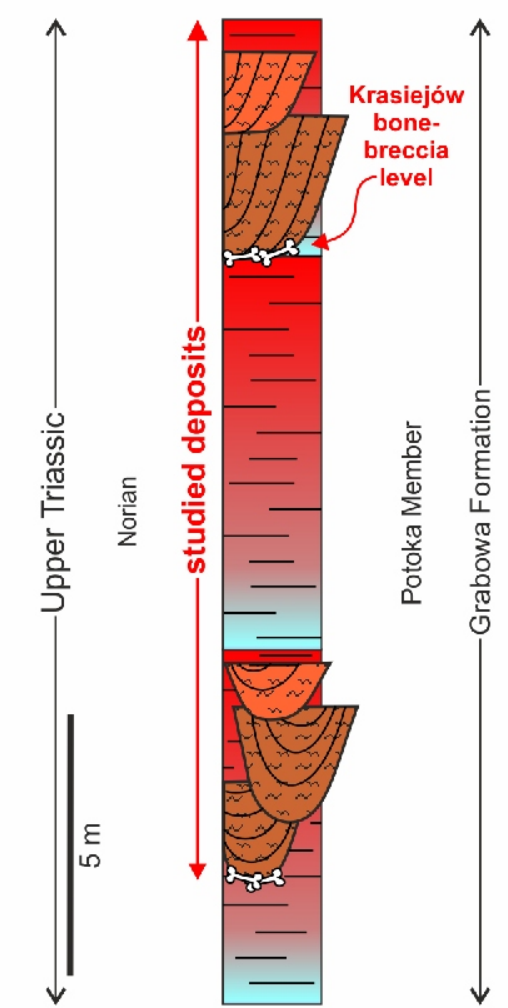

B

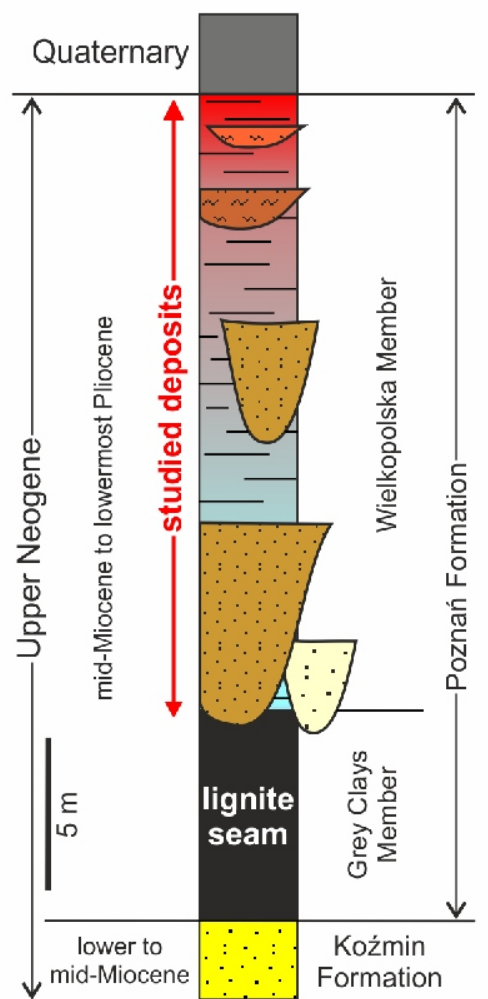

C

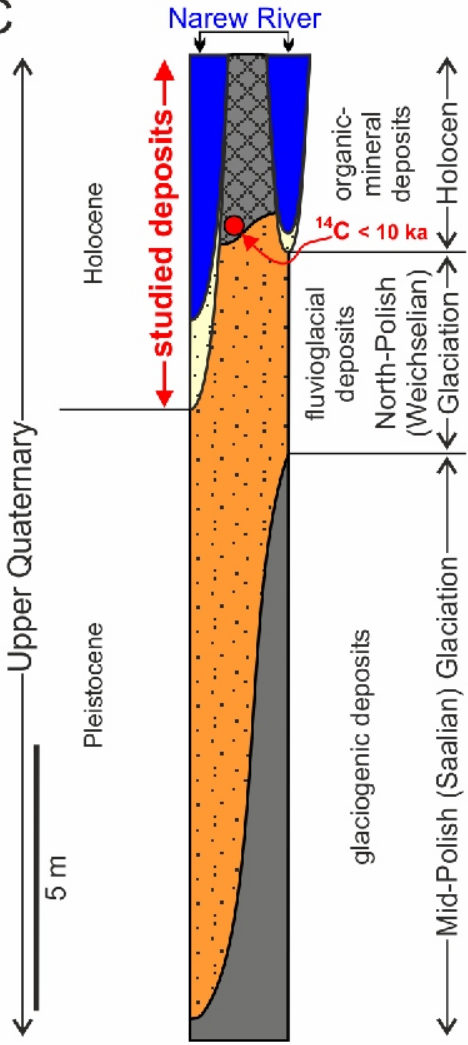

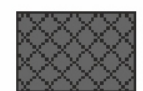

organic-mineral deposits (peat, sandy peat) bone$\varepsilon \approx 3$ bearing horizon

glaciogenic deposits
(till, gravel, sand, mud)

fluvioglacial deposits (gravel, sand)

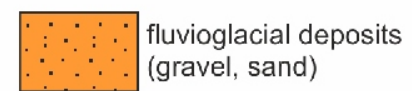

$\because$ sandy
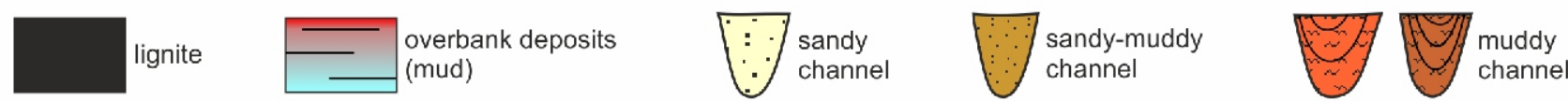

Fig. 2. Simplified lithostratigraphy of the sections studied

A - schematic section of the upper Triassic succession in the Krasiejów section; note the stratigraphic position of bone-bearing horizons (modified from Gruszka and Zieliński, 2008; Szulc and Racki, 2015; Szulc et al., 2015; Jewuła et al., 2019); B - schematic section of the upper Neogene in the Konin lignite opencasts; note that the palaeochannel-fills transform upwards from sandy to muddy (modified from Widera, 2013; Maciaszek et al., 2019); C - schematic section of the upper Quaternary of the upper Narew River; note that the oldest radiocarbon dates for peat are <10 ka (modified from Gradziński et al., 2000, 2003a, b); see Figure 1 for approximate location of the sections

Table 1

Letter code used in this paper for sedimentary facies shown in this contribution (modified from Miall, 1977; Ghibaudo, 1992; Widera et al., 2019)

\begin{tabular}{|c|c|}
\hline Code & Granulometry \\
\hline$G$ & gravel, conglomerate \\
S & sand, sandstone \\
M & mud, mudstone \\
T & silt, siltstone \\
Y & clay, claystone \\
C & coal, carbonaceous \\
\hline Code & Sedimentary structure \\
\hline m & massive \\
h & horizontal (plane-parallel) lamination \\
p & planar cross-stratification \\
t & trough cross-stratification \\
I & low-angle cross-stratification \\
r & ripple cross-lamination \\
rc & climbing-ripple cross-lamination \\
f & flaser lamination \\
n & nodular (lenticular) lamination \\
w & wavy lamination \\
\hline
\end{tabular}

\section{RESULTS}

\section{TRIASSIC AND NEOGENE ANASTOMOSING ALLUVIUM IN THE ROCK RECORD}

\section{GENERAL CHARACTERISTICS OF THE TRIASSIC DEPOSITS}

The Keuper (Norian) sedimentary succession is exposed in a large, abandoned brickyard exploiting Upper Triassic claystones (cf. Figs. 2A and 3). Due to the discovery of numerous vertebrates (amphibians and reptiles), this section has become the subject of numerous palaeontological studies (for references see Szulc et al., 2015; Kowalski et al., 2019). This famous site is today a well-known geotourist centre - the Jura Park Krasiejów, where the bone remains are displayed in situ. The palaeobiological research required additional sedimentological analyses to highlight the environment of life and burial of the vertebrates. An initial study was published by Bilan (1975), inferring a Norian palaeoenvironment with sedimentation in meandering rivers, succeeded by brackish sea conditions. Subsequent studies, Dzik et al. (2000) and Dzik (2003) suggested the idea that the Krasiejów succession accumulated 

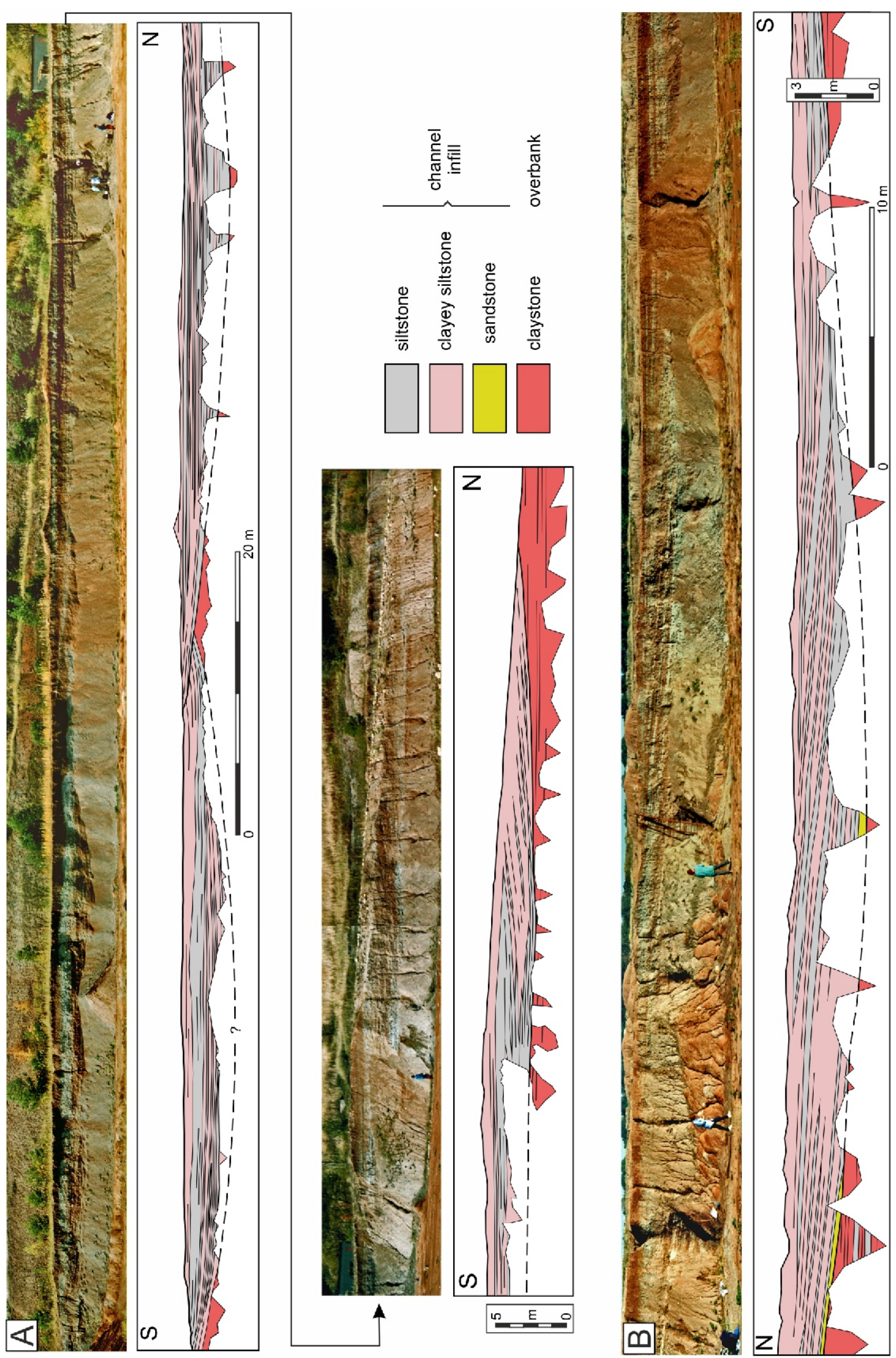

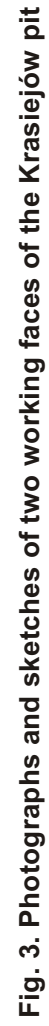




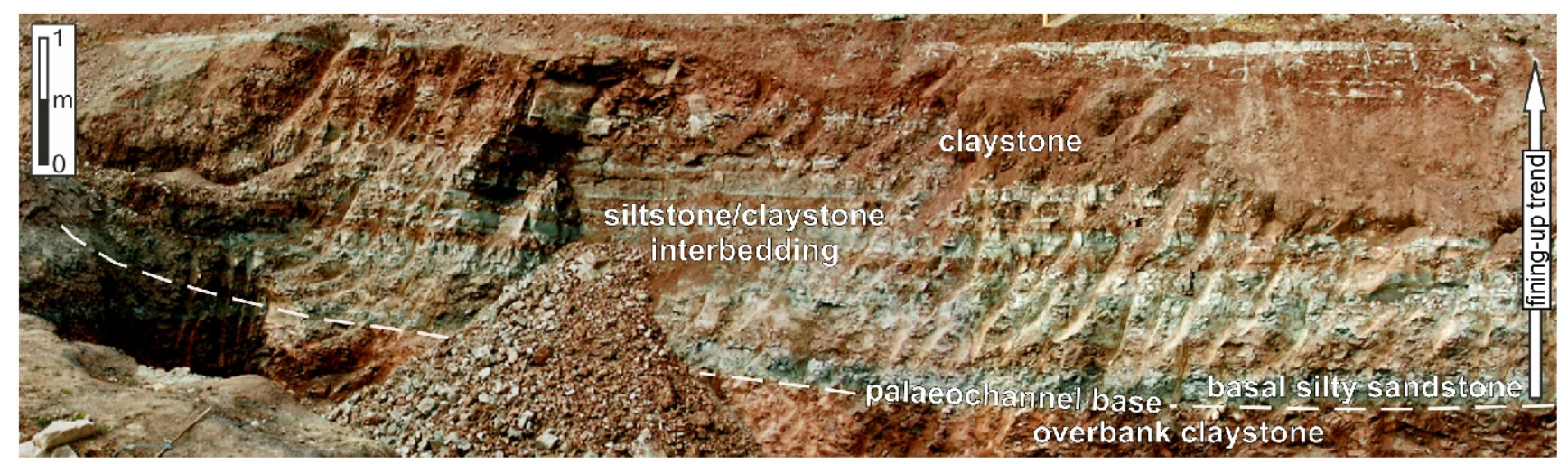

Fig. 4. Typical channel infill of the Krasiejów site

Note the convex-down erosional bottom of the palaeochannel and the fining-up infill starting from a silty sandstone layer at the base, through a siltstone/claystone rhythmic package, to a claystone interval above

partly in an alluvial plain environment, and partly under the conditions of a lake and marine delta (see Fig. 1D). The lacustrine hypothesis of the origin of the mudstones was repeated by Dzik and Sulej (2007). In contrast, Szulc (2005) concluded that the sedimentary environment was represented by an alluvial fan dominated by debris-flow processes. Szulc et al. (2015) interpreted the depositional environment of the Krasiejów basin as a playa with numerous lakes developed in a gilgai-type topography (i.e., shallow depressions in muddy terrain generated by pedogenic processes). Jewuła et al. (2019) also interpreted the palaeoenvironment as a playa plain with gilgai ephemeral ponds, meandering, braided, and anastomosing rivers. The interpretation of the Krasiejów mudstones as a record of an alluvial plain within an anastomosing river system was first proposed by Gruszka and Zieliński (2008); two fluvial units, separated by lacustrine claystones, were distinguished. In the lower part of the sedimentary succession, they documented muddy infills of some alluvial channels, which were identified as corresponding to the mud-dominated class of anabranching rivers (Gruszka and Zieliński, 2008).

\section{DESCRIPTION OF CHANNEL FACIES ASSOCIATION}

The palaeochannels are 60-150 m wide and 2-4.5 m deep, with concave-up erosional bases. The uppermost parts of the channel infill are often truncated by younger palaeochannels (Fig. 3). The main channel facies is a succession of $15-30 \mathrm{~cm}$ thick siltstones and thinner claystones. The ratio of the total thickness of siltstone to claystone layers is $4: 1$ (Gruszka and Zieliński, 2008). The frequency of claystone layers clearly increases towards the top of the infills that generally show normal grain-size grading (Fig. 4). In other cases, the channel-fill deposits gradually pass into overbank facies. The channel infill locally commences with a thin $(5-20 \mathrm{~cm})$ layer of coarse-grained sandstone or granule-sized conglomerate, most commonly sandy (cf. Figs. 3B and 5), consisting of grains of soil-derived calcareous nodules (Szulc, 2005). The siltstone beds are characterized by horizontal lamination (Th), ripples, or climbing-ripple cross-lamination ( $\mathrm{Tr}, \mathrm{Trc}$ ) and massive structures (Tm). The claystones, sandstones and sandy conglomerates are always massive (Ym, Sm, GSm). In some parts, these siltstone and claystone beds are arranged in $20-40 \mathrm{~cm}$ thick normally graded (fining-upwards) successions: $\mathrm{TSr} \Rightarrow \mathrm{Th}, \mathrm{TSr} \Rightarrow \mathrm{Th} \Rightarrow \mathrm{Ym}, \mathrm{TSr}$ $\Rightarrow \mathrm{TSrc} \Rightarrow \mathrm{Ym}$ (Fig. 5 and Table 2). Reverse graded (coarsening-upwards) successions were noted too, although they are less frequent. Layers of siltstone, mudstone and claystone con-

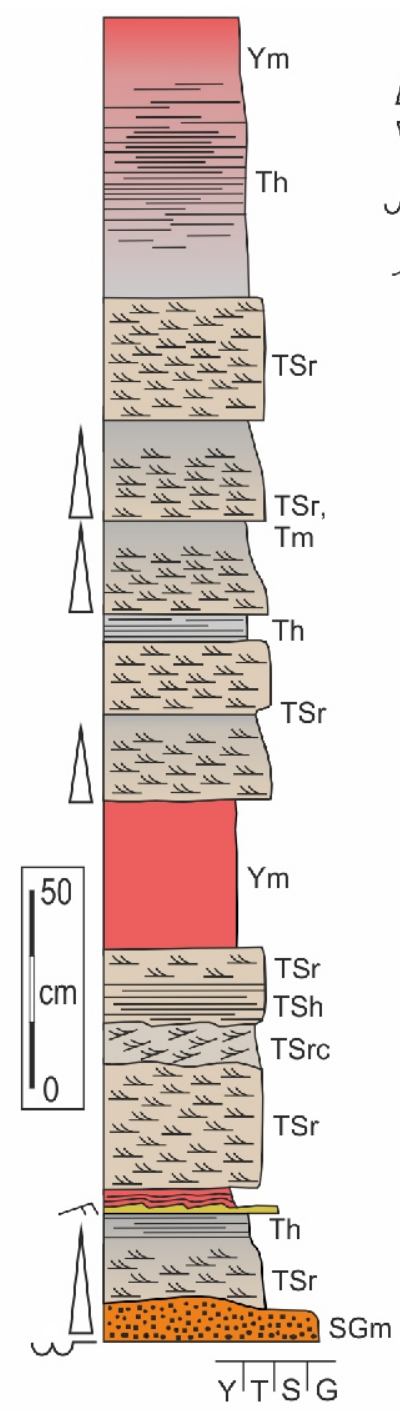
$\bigwedge$ fining-up succession
$\nabla$ coarsening-up succession
$u$ erosional contact
(palaeochannel bottom)
h horizon of fossil ripples

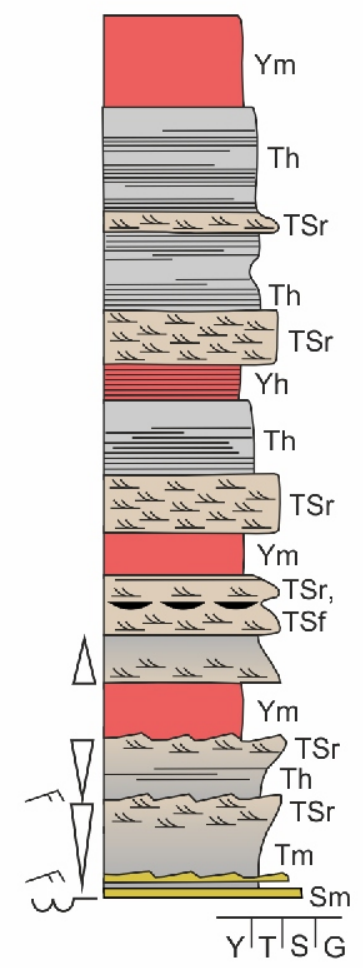

Fig. 5. Two typical sedimentary logs of palaeochannels found at the Krasiejów site (modified from Gruszka and Zieliński, 2008)

See Table 1 for facies code 
Sedimentological characteristics of the in-channel and overbank facies typical of the late Triassic anastomosing fluvial system at the Krasiejów site, southern Poland (modified from Gruszka and Zieliński, 2008)

\begin{tabular}{|c|c|c|c|}
\hline Facies & Code & Description & Interpretation \\
\hline \multicolumn{4}{|c|}{ In-channel facies } \\
\hline $\begin{array}{l}\text { Massive sandstone, } \\
\text { silty sandstone, } \\
\text { sandy conglomerate }\end{array}$ & $\begin{array}{l}\text { Sm, SFm, } \\
\text { GSm }\end{array}$ & $\begin{array}{l}\text { Only in palaeochannel bottoms, as long, } \\
\text { thin ( } 5-20 \mathrm{~cm} \text { ) lenses forming the lower- } \\
\text { most beds; erosional bases; calcareous } \\
\text { nodules as granule-sized grains }\end{array}$ & $\begin{array}{l}\text { Initial accumulation following the channel erosion; } \\
\text { sudden but short-term deposition from bedload } \\
\text { transport, upper plane bed conditions; redeposition } \\
\text { of calcareous nodules from overbank deposits }\end{array}$ \\
\hline $\begin{array}{l}\text { Siltstone with hori- } \\
\text { zontal (plane-paral- } \\
\text { lel) lamination, ripple } \\
\text { (climbing ripple) } \\
\text { cross-lamination, } \\
\text { massive structure }\end{array}$ & $\begin{array}{c}\text { Th, Tr, Trc, } \\
\text { Tm }\end{array}$ & $\begin{array}{l}\text { Present in lower and middle parts of the } \\
\text { channel bodies; sheet-like beds } 15-25 \mathrm{~cm} \\
\text { thick; thickness and frequency decrease to } \\
\text { the channel-fill top; coexistence with clay } \\
\text { beds in rhythmic arrangement or in graded } \\
\text { couplets } 20-40 \mathrm{~cm} \text { thick }\end{array}$ & $\begin{array}{l}\text { Low-energy deposition, mainly from suspension, } \\
\text { secondarily from bedload; plane bed or ripple con- } \\
\text { figuration; flow velocity } v \approx 0.1 \mathrm{~ms}^{-1}, \text { flow power } \omega \approx \\
1 \mathrm{Wm}^{-2} \text {; periodic changes from weak currents to } \\
\text { stagnant waters; gradual decline of currents during } \\
\text { the channel aggradation }\end{array}$ \\
\hline $\begin{array}{l}\text { Massive claystone or } \\
\text { silty claystone }\end{array}$ & Ym, YTm & $\begin{array}{c}\text { Present in middle and upper parts of the } \\
\text { channels; sheet-like beds } 10-20 \mathrm{~cm} \text { thick; } \\
\text { thickness and frequency increase to the } \\
\text { channel-fill top; coexistence with silt beds } \\
\text { as rhythmite or in graded couplets } 20-40 \\
\mathrm{~cm} \text { thick; } 20-60 \mathrm{~cm} \text { thick clay intervals end } \\
\text { channel infills }\end{array}$ & $\begin{array}{l}\text { Standing water conditions; deposition from } \\
\text { fine-grained suspension; periods of flow cessation } \\
\text { during the main phase of channel aggradation; final } \\
\text { accumulation during channel abandoning }\end{array}$ \\
\hline \multicolumn{4}{|c|}{ Overbank facies } \\
\hline $\begin{array}{l}\text { Massive claystone or } \\
\text { silty claystone }\end{array}$ & Ym, YTm & $\begin{array}{c}\text { Homogenous, thick (c. several m), amal- } \\
\text { gamated intervals; red/brown and sil- } \\
\text { ver/grey 'layers' } 15-30 \mathrm{~cm} \text { thick; microfaults } \\
\text { dipping at } 30-50^{\circ} \text {, converging each other, } \\
\text { marked with grey clay laminae; horizons of } \\
\text { calcareous nodules } 3-5 \mathrm{~cm} \text {; traces of mud } \\
\text { cracks }\end{array}$ & $\begin{array}{l}\text { Standing water conditions in flood basins; submer- } \\
\text { gence of the whole floodplain; deposition from the } \\
\text { finest (uniform and pelagic) suspension; periodic } \\
\text { emergence and drying of ground surface in hot cli- } \\
\text { mate - development of vertisols }\end{array}$ \\
\hline
\end{tabular}

tinue across the entire width of the palaeochannels (see Fig. $3 \mathrm{~A}$ ), and rest almost conformably with erosive channel bottoms that slope downwards at a dip angle less than $10^{\circ}$. Most often their thickness is almost constant along the entire distance of the exposure. As a rule, individual beds are slightly asymmetrical and shifted to the south in relation to the channel axes (see Fig. 3B).

\section{INTERPRETATION}

The palaeochannels examined are clearly fine-grained with silt and clay contents of $\sim 90$ wt. $\%$. Their analysis using the method of Passega (1977) indicated deposition from uniform suspension deposition (Fig. 6). This analysis also showed that the energetic conditions of deposition were intermediate between lacustrine standing waters (pelagic suspension) and the hydrodynamics of a meandering river environment (graded suspension with secondary saltation and uniform suspension; Fig. 6). Analysis of the textures (grain size) and structures (height of current and climbing ripples) of the channel deposits showed that ripple formation took place at flows of $\sim 0.1 \mathrm{~m} \cdot \mathrm{s}^{-1}$, with very low stream power $\left(\omega \approx 1 \mathrm{~W} \cdot \mathrm{m}^{-2}\right)$. The directional distribution of sedimentary structures obtained from channel infills (i.e., from current and climbing ripples) covered the entire range of the $360^{\circ}$ azimuth rose (Fig. 7). This could be evidence that the river system was anabranched and the channels were oriented at high angles to each other. The sinuosity ratio of these ancient channels at $s n=1.27$ was also calculated based on the lamination orientation, which classifies the palaeochannels as being moderately sinuous according to the classification of Brice (1964). The spatial arrangement of the beds, concordant to the channel bases, and the lack of clear erosive surfaces indicated the aggradational nature of the palaeochannel facies. Despite the fact that sedimentation took place within the river bends (from the asymmetrical shape of the channel bodies), no sedimentary structures typical of point bars, such as inclined lamination, were found. Fossil ripples (current and climbing) are the only bedforms present, while large-scale depositional forms were not observed. These features indicated vertical, and not lateral, accretion, characteristic of the river sedimentation style. Thus, these ancient channels, although they were moderately sinuous, did not migrate laterally due to the low energy of the flows and the high resistance to erosion of the cohesive clay banks. The width-to-thickness ratio (w/t) of the four channels was in the range 27-60 (cf. Figs. 3 and 4).

DESCRIPTION OF THE OVERBANK FACIES ASSOCIATION

The overbank facies association is a monotonous succession of mainly horizontally laminated silty clays and clays (Table 2). The contacts of the beds are ill-defined due to very small grain-size differences. Sandy intercalations were not found in this overbank facies association. The colour of the deposits alternates between red/brown and silver/grey in successive layers $15-30 \mathrm{~cm}$ thick, that also contain pedogenic structures with microfaults converging at an angle of $100-130^{\circ}$. These were marked within thin $(\sim 0.5 \mathrm{~cm})$ laminae of grey clay with horizons of calcareous nodules $(3-5 \mathrm{~cm}$ in diameter) above the microfaults (Fig. 8). Mud crack structures have been also found at various stratigraphic levels.

\section{INTERPRETATION}

These overbank deposits accumulated in stagnant water conditions of the flood basins in the inter-channel areas. So far, no facies have been found that could be interpreted as natural levees or crevasse splays. The inter-channel areas underwent cyclic emergence and drying as indicated by colour change, occurrence of mudcracks, and pedogenic signature-related structures. In this way, vertisols with characteristic slickensides (present on the surfaces of complementary faults; Fig. 8) were developed on the muddy ground (Gruszka and Zieliński, 2008), 


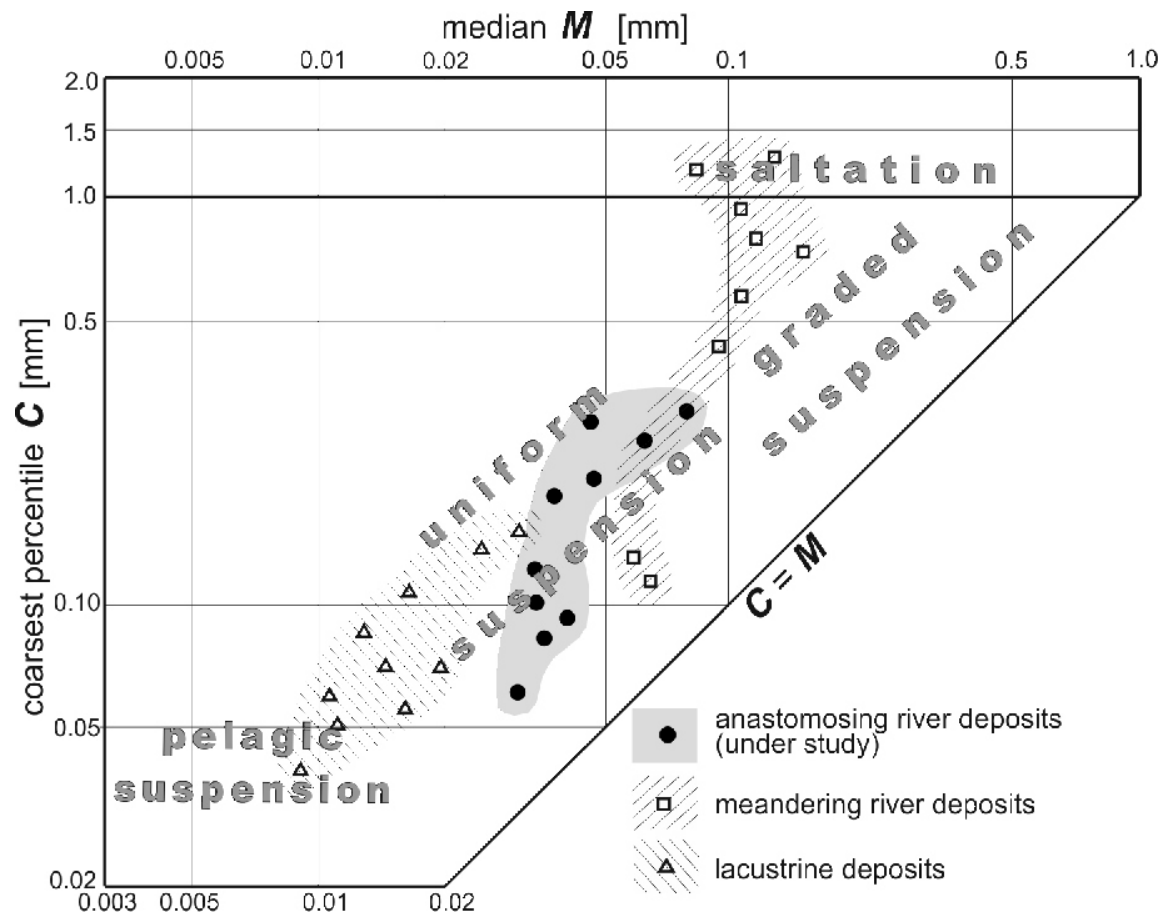

Fig. 6. Passega diagram depicting the differences of texture and depositional mechanisms of three successions exposed in the Krasiejów pit (modified from Gruszka and Zieliński, 2008)

See Figure 2A for location of fluvial and lacustrine successions

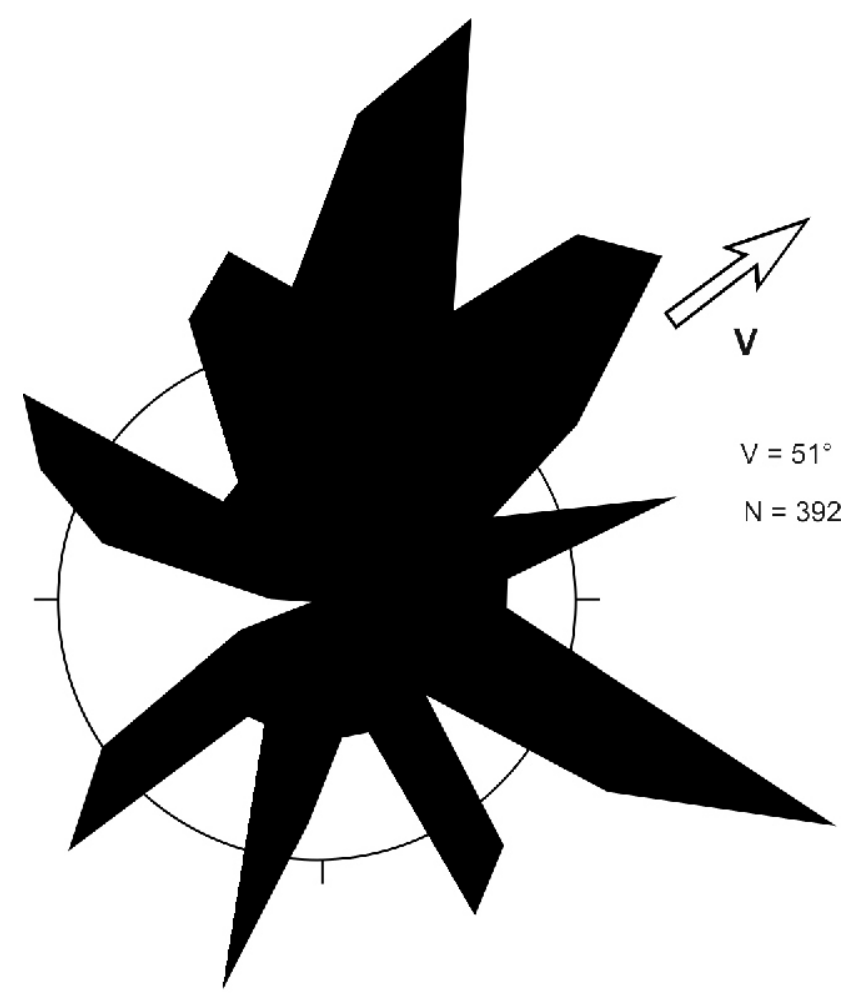

Fig. 7. Azimuth rose of cross-laminated beds (current and climbing ripples) from the Krasiejów fluvial succession (data from four channel infills)

$\mathrm{V}$ - mean vector, $\mathrm{N}$ - number of measurements; modified from Gruszka and Zieliński (2008) being a typical feature of a semi-tropical climate (Therrien and Fastovsky, 2000).

\section{PALAEOCHANNEL PATTERN AND PALAEORIVER TYPE}

The succession accumulated in a system of several moderately sinuous channels that existed on a flat, clayey, alluvial plain. Channel flows were of very low energy (average $\mathrm{v} \approx$ $0.1 \mathrm{~m} \cdot \mathrm{s}^{-1}$, average $\omega \approx 1 \mathrm{~W} \cdot \mathrm{m}^{-2}$ ), the basic feature of anastomosing rivers (cf. Nanson and Crooke, 1992; Makaske, 1998; Latrubesse, 2015). The weak flows allowed the deposi-

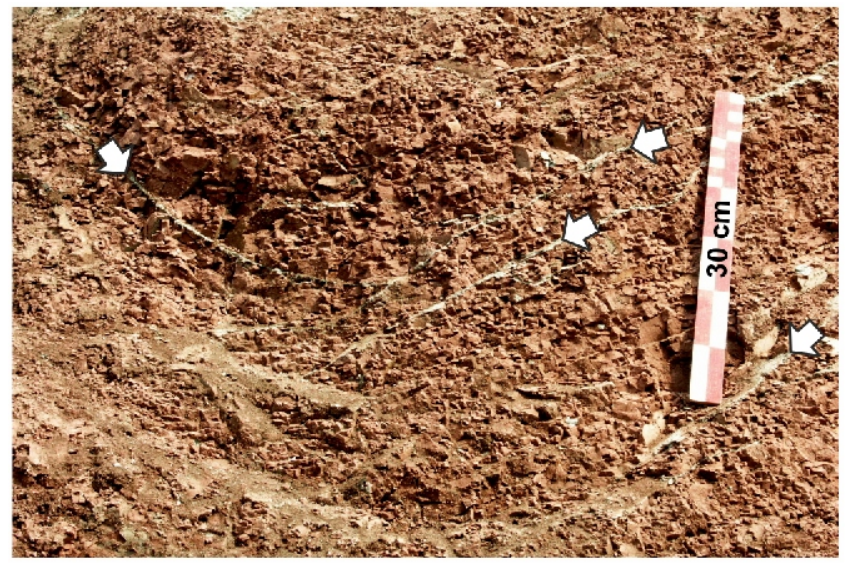

Fig. 8. Overbank clay interval in the Krasiejów site

Light clay laminae (arrowed) mark microfaults (slickensides) that resulted from seasonal wetting and drying pedogenic processes in a semi-arid climate 
tion of silt and clay as layers with a massive structure, horizontal lamination, and ripple cross-lamination. Such a facies association is very similar to the anastomosing river successions described by Eberth and Miall (1991), Mack et al. (2003) and Kraus and Davies-Vollum (2004). There were no bars in the channels, and the only bedforms were current ripples, often climbing. Vertical accretion dominated by suspended load is considered as an indicator of anastomosing rivers (e.g., Jones and Schumm, 1999; Makaske et al., 2009). Uniform vertical accretion of fine-grained material took place, across the entire cross-sections of the channels, from flows with a high concentration of suspended load. During floods, the alluvial plains were completely submerged and clays were mostly deposited from stagnant waters in the inter-channel zones. Analogous overbank deposits have been reported by Mack et al. (2003) and Ghosh et al. (2006) from fossil alluvial plains of anastomosing rivers. Notably, Gruszka and Zieliński (2008) did not find, in the Krasiejów section, overbank facies that would indicate the formation of natural levees and crevasse splays. These forms are considered to be abundant in humid anastomosing river environments (Hill et al., 2001; Latrubesse and Franzinelli, 2002; Makaske et al., 2017). Their absence is consistent with deposition in a dry climate (cf. North et al., 2007), prevailing during the sedimentation of the Krasiejów succession. Such rivers of dry and semi-arid climate zones constitute a specific fluvial group referred to as suspended-load channels (sensu Schumm, 1972) or mud-dominated systems (sensu Nanson et al., 1988). The bedload of these rivers is so negligible that natural levees crevasses and crevasse splays are not formed (Törnqvist et al., 1993). Moreover, if levees and crevasse splays in such rivers exist, they are built of mud beds (Mack et al., 2003) which are practically the same as the other overbank sediments of these flood basins. Summing up, most of the evidence indicates that the sedimentary environment of the succession analysed was one of an anastomosing river system (Gruszka and Zieliński, 2008). The palaeochannels examined were relatively wide and shallow. Their width-to-thickness ratio is relatively high $(27<w / t<60)$, while in classic models of anastomosing rivers this parameter is in the range of $3-55$, and most often $<15$ (see discussion in Widera, 2013 and references therein). This paradox may be explained by the fact that the avulsive palaeochannels, formed by high-energy flows, were incised into clayey, extremely cohesive, and erosion-resistant substrata. Similar minor erosion, even during large floods, was reported by Nanson et al. (1993) from anastomosing rivers in Australia.

MODERN MUD-DOMINATED ANALOGUES

The climatic factor is significant in the search for present-day analogues of the Triassic fluvial system of Krasiejów. The abundant presence of vertisols with well-developed slickenside structures and carbonate nodules within overbank deposits indicate that a tropical semiarid climate with distinctly seasonal precipitation prevailed (Gruszka and Zieliński, 2008; Szulc and Racki, 2015). In many studies of anastomosing rivers, such vertisol-type soils have been documented in the overbank deposits (Gibling et al., 1998; Kraus, 2002; Ghosh et al., 2006; Simon and Gibling, 2017).

A review of the sedimentological literature shows that the Krasiejów succession, lacking crevasse-splay facies, may be compared with rivers in the semiarid climate zone of central Australia. These are the Cooper Creek and Diamantina rivers (Rust and Nanson, 1986; Nanson et al., 1988), of a mud-dominated anabranching system according to the classification of Nanson and Knighton (1996). Both these adjacent river basins occur within the hot semiarid and arid climate zones, where the mean annual precipitation is $135-415 \mathrm{~mm} \cdot \mathrm{y}^{-1}$. For example, the Cooper Creek has a very small slope $(S=0.0002)$ and flow power $\left(2<\omega<5 \mathrm{~W} \cdot \mathrm{m}^{-2}\right)$. The clayey floodplain is up to $60 \mathrm{~km}$ wide, while the numerous channels have $\mathrm{w} / \mathrm{d}$ ratios close to 10 (Rust and Nanson, 1986; Nanson et al., 1988; Gibling et al., 1998).

In the late Triassic, the Krasiejów region most likely resembled a denudated broad, low relief plain, where river slopes and flow energy were very small. The semi-tropical climate was conducive to intense chemical weathering - the eluvium formed was mainly clayey (Środoń et al., 2014). River flows were characterized by a high concentration of suspended load. Thus, the multi-channel river transported and deposited fine-grained sediments via vertical accretion. These relatively shallow channels became filled with sediment, which most likely forced avulsions, resulting in the anastomosing river system (Gruszka and Zieliński, 2008). However, infill of the channels after avulsion, for example, during subsequent floods, is also possible.

\section{NEOGENE ANASTOMOSIING RIVER}

GENERAL CHARACTERISTICS OF THE NEOGENE DEPOSITS

Scientific and economic interest in the fine-grained (>95 vol.\% mud) Neogene deposits studied stems from their having been glaciotectonically disturbed and exposed in the field. Therefore, they have often been easily mined for brick production from at least the sixteenth century in central-western Poland (Maciaszek et al., 2020). This muddy succession has been studied in detail for the last 150 years, as summarised by Piwocki et al. (2004). Three hypotheses regarding its formation have emerged: lacustrine, lacustrine-marine-alluvial, and fluvial. Thus, for over 100 years (until the early 1960s), this uppermost Neogene succession was attributed to a "Pliocene Lake" (Areń, 1964), from evidence such as the shape of the sedimentary basin (see Fig. 1C). In the following two decades, some researchers noted traces of marine influence and alluvial fans within the muds of the southern part of the inferred lake basin (Dyjor, 1970; Ciuk and Pożaryska, 1982). Most recently, a fluvial hypothesis for the deposition of the sediments was suggested, but without providing evidence in the form of field observations (Badura and Przybylski, 2004; Piwocki et al., 2004). This gap, that has stimulated our work in the last decade, is documented below in the form of sedimentological characterisation of both channel and overbank deposits.

DESCRIPTION OF CHANNEL FACIES ASSOCIATION

Fluvial palaeochannels, encased in mud-rich deposits, are located at various stratigraphic levels and have different lithological infills (Fig. 9). Most of these channels are situated in the basal parts of the muddy succession, occasionally incising into the underlying lignite seams (cf. Fig. 2B). They are predominantly filled with sand and mud, or their mixture, while sand-dominated channels are also present. In the latter case, they are filled with fine-grained massive sands (Fig. 9A, B). Channels located higher in the section are often strongly glaciotectonically deformed (Fig. 9C, D). Mud-dominated channels are also present, the infill of which is texturally similar to the surrounding muddy deposits (Fig. 9E, F). These channel types are important in understanding the geological history of the sedimentary succession, but their usefulness in facies analysis is limited due to their massive structure and/or deformation. Therefore, their most common and/or diagnostic facies will be characterized below only if they are not clearly post-depositionally deformed (Figs. 10, 11 and Table 3). 

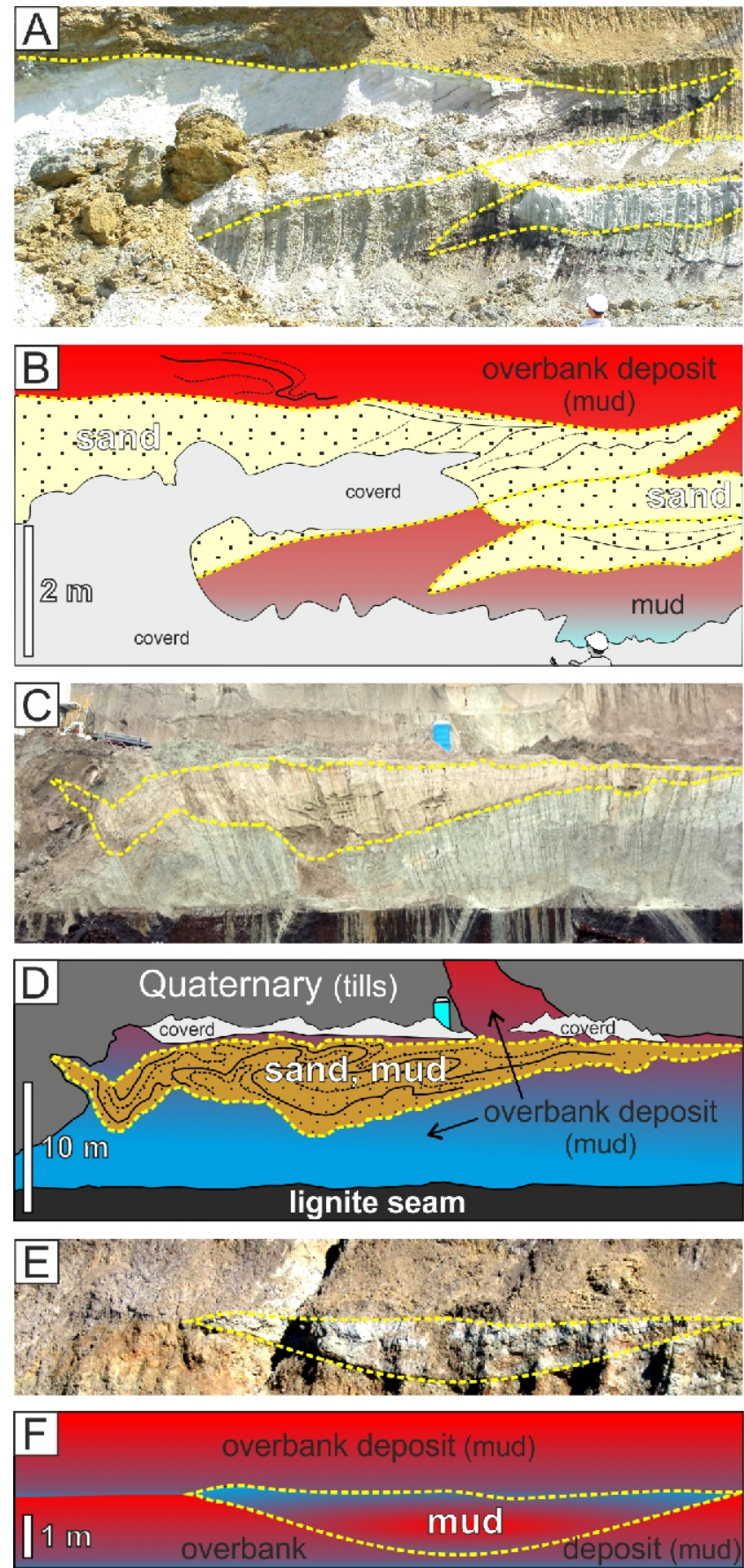

Fig. 9. Examples of palaeochannel-fill sediments of different lithology (general views and their corresponding line drawings)

A, B - sand-dominated channel-fills; note the glaciotectonically thrust and folded overbank muddy deposits (Kazimierz North lignite opencast, 2008); C, D - sand- and mud-dominated channel-fills; note the glaciotectonically folded within-channel deposits (Jóźwin IIB lignite opencast, 2020); E, F - mud-dominated channel-fills (Kazimierz North lignite opencast, 2006)

Most of the facies descriptions come from the largest ( $150 \mathrm{~m}$ wide and $12 \mathrm{~m}$ thick) sandy-muddy channel deposit (Fig. 10A, B), which was exposed in 2018 in the Jóźwin IIB opencast belonging to the Konin Lignite Mine. This channel deposit, like some other primary channels (formed during avulsion at high water stages) was incised into the surrounding muds and an underlying lignite seam. The erosional base is concave upwards and commonly lined by a channel lag, which contains xylites (i.e., fossilized wood fragments $>1 \mathrm{~cm}$ in size), mud balls (Fig. 10C), and redeposited quartz gravels of Oligocene age (cf. Widera et al., 2019: fig. 6B). In general, large-scale sandy facies (i.e., thicker than $10 \mathrm{~cm}$ ) prevail in the lower part of the primary channels, and they are mostly trough and planar cross-stratified, as well as plane-parallel (horizontally) stratified, that is, facies St, Sp, and Sh. Nevertheless, going from the base to the top of the channel infill, some laminae are enriched in organic detritus (lignite) or mud. In that case, the following composite facies are distinguished: SCt, SMt, SMp, and SMh (Fig. 10D-F). The mud content increases upwards in the section described, especially in the secondary channels that formed during filling of the primary channel. This results in the distinction of such muddy and sandy-muddy facies as: Mt, Mh, Mm, MSt, SMh, and STt (Fig. 10G-I). Current ripples are the most common small-scale sedimentary structures (Sr, STr) in all parts of the sandy and sandy-muddy channels (Fig. 11A). However, other types of small-scale sedimentary structure are found only in the secondary channels. These structures are climbing-ripple cross-lamination (Src, STrc) and heterolithic bedding, that is, flaser (Sf), wavy (Sw) and lenticular/nodular (Sn; Fig. 11B-D).

INTERPRETATION

Facies interpretation shows that the palaeochannel-fill sediments were generally formed under low-energy flow conditions, interrupted most likely by floods, as shown by the estimated flow power ranging between 2.5 and $21 \mathrm{~W} \cdot \mathrm{m}^{-2}$ (Zieliński and Widera, 2020). Nevertheless, the presence of ripple-related structures, especially heterolithic bedding, points to relatively long periods when the flow velocity was $<0.5 \mathrm{~m} \cdot \mathrm{s}^{-1}$ to near-stagnant water (Table 3 ). Thus, with extremely low water flow velocities, mud was deposited predominantly from suspension, but when the water flowed faster sand-grade particles were deposited, mainly from traction (e.g., Reineck and Singh, 1980; Martin, 2000; Maciaszek et al., 2019). Based on the cross-sectional geometry of more than 30 primary channels these can be classified as broad ribbons (Gibling, 2006), because their average $\mathrm{w} / \mathrm{t}$ ratio was in the range of 5-15 (Widera, 2013; Widera et al., $2017,2019)$. On the other hand, the secondary channels, which existed at the time of infill of the primary ones, were characterized by higher values of aspect ratio $(w / t=15-30)$ and traces of lateral accretion, that is, they were meandering (Zieliński and Widera, 2020). This is apparently contradictory as the flow energy was many times greater when the primary channels were formed; however, the lateral mobility of the secondary channels was slightly greater. These differences may be explained by significantly greater resistance to erosion in the overbank muds (more cohesive) than the in-channel sandy-muddy sediments.

DESCRIPTION OF OVERBANK FACIES ASSOCIATION

The deposits encasing the channel bodies, referred to as muds in this contribution, contain fine-grained particles, namely clay, silt, and sand, in approximately equal proportions (Widera, 2007). This was often as a mixture of these fractions, but some almost purely clayey or silty layers or lenses (up to $0.5 \mathrm{~m}$ thick and up to $>10 \mathrm{~m}$ wide) also occur within this sedimentary association. These predominantly muddy facies ( $\mathrm{Mm}, \mathrm{Mh}$ ) show a wide range of colours from dark blue to blood red. Furthermore, they include well-developed grey to black horizons - facies $\mathrm{MCm}$ and $\mathrm{Cm}$. These were observed in the field over a length from a few to hundreds of metres (Fig. 12). 

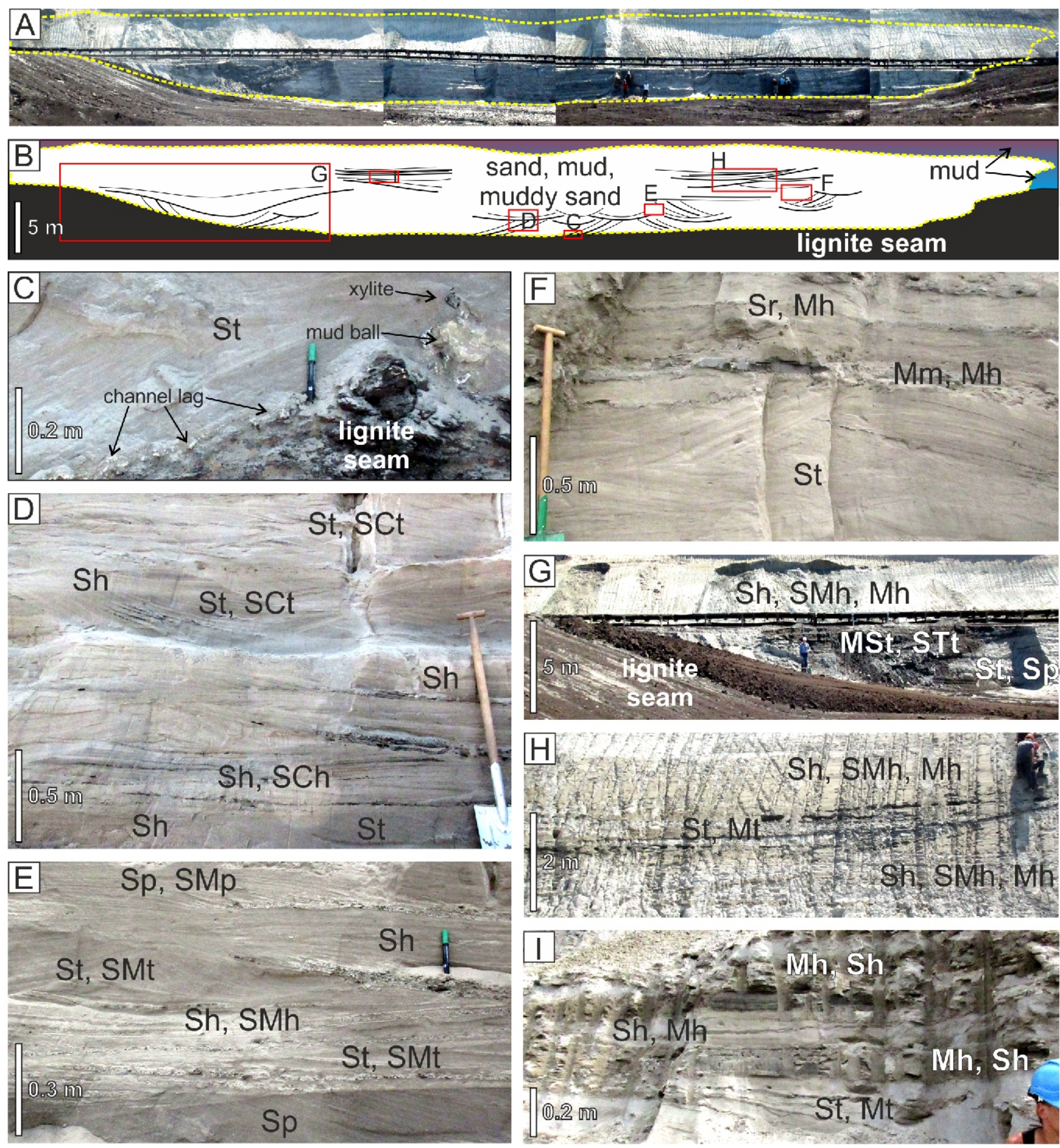

Fig. 10. Large-scale facies representative of sandy-muddy palaeochannels

A, B - broad eastward view and corresponding line-drawing of the largest sandy-muddy palaeochannel; note the approximate location of the photographs posted below in order from the channel base upwards (Jóźwin IIB lignite opencast, 2018); C - erosive contact between the lignite seam and the channel base, note the presence of a gravelly channel lag, mud balls and xylites; $\mathbf{D}$ - facies with stratification emphasized by carbonaceous (lignite) detritus; $\mathbf{E}$ - facies with stratification emphasized by increased mud content; $\mathbf{F}$ - sandy facies separated (overlain) by muddy facies; $\mathrm{G}$ - a channel incised (by up to $5 \mathrm{~m}$ ) into the lignite seam; note that the secondary (muddy) channel is cut into the primary (sandy) one; $\mathbf{H}, \mathbf{I}$ - the sandy and muddy deposits in the middle and upper part of the primary channel; note the presence of secondary channels-fill of the same lithology; see Table 1 for facies codes 

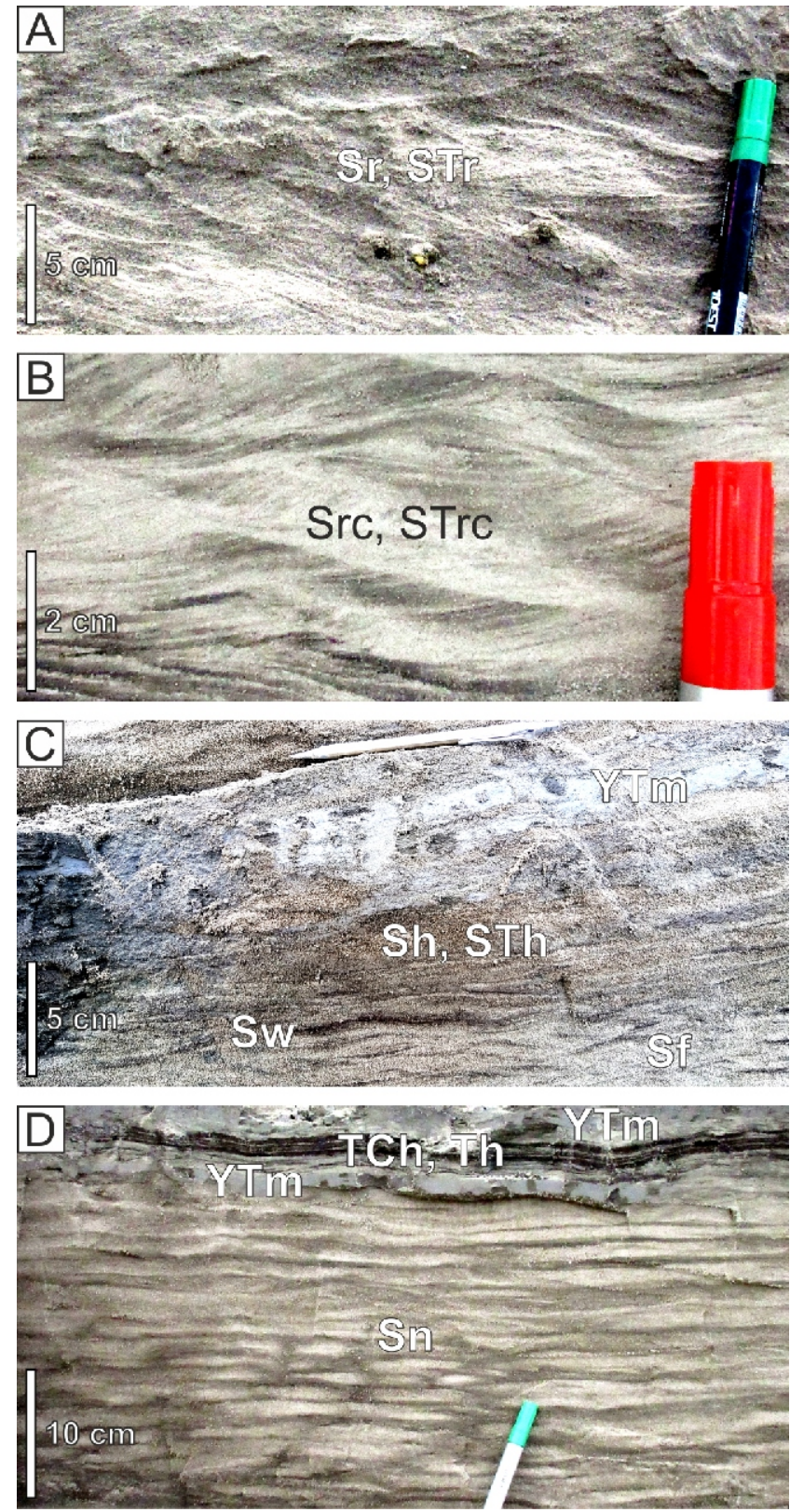

Fig. 11. Specific small-scale facies characteristic of low-energy flows

A - sand and silty sand with ripple cross-lamination; B - sand and silty sand with climbing-ripple cross-lamination; $\mathbf{C}$ - sand with flaser and wavy bedding; note less or more (darker) discontinuous muddy layers; D - sands and muddy sands with lenticular (nodular) bedding; note sandy lenses (lighter) and muddy-sandy background, see Table 1 for facies codes

\section{INTERPRETATION}

The interpretation of the muddy facies with a massive structure and horizontal lamination seems obvious in the context of the numerous river channels among them (Table 3 ). Their terrestrial (fluvial) origin is supported by the results of mineralogical studies that indicate the dominance of smectite among the clay minerals (e.g., Wyrwicki and Wiewióra, 1981; DuczmalCzernikiewicz, 2013). Most likely, the muds were deposited on a floodplain. At that time, fluctuations in the groundwater level were significant, as shown by the varied oxidation-related colours of the muds (Piwocki et al., 2004; Widera, 2007). Thus, the grey-black layers, interpreted as hydromorphic palaeosols, developed on alluvial plains under conditions of a relatively high groundwater level, while the yellowish to reddish beds were formed when the groundwater level was low. The best evidence for the existence of subaerial conditions is the presence of thin layers of lignite at the top of the palaeosols - facies $\mathrm{Cm}$ (Fig. 12B, C). Such lignite beds within this muddy succession, being from several $\mathrm{cm}$ to $>10 \mathrm{~m}$ thick, are also known from other parts of Poland (e.g., Piwocki and Ziembińska-Tworzydło, 1997; Piwocki et al., 2004; Widera, 2012, 2021; Urbański and Widera, 2016; Maciaszek et al., 2020). The formation of $1 \mathrm{~m}$ of lignite in the late Neogene strata of central Poland was estimated to have occurred over a period of 40 ky (Chomiak, 2020; Widera et al., 2021b). This clearly indicates that some parts of the sedimentary basin experienced long intervals without siliciclastic (muddy) deposition.

PALAEOCHANNEL PATTERN AND PALAEORIVER TYPE

The palaeochannels, seen in cross-section, are located both at the same (Fig. 13A) and at different stratigraphic levels, that is, arranged multi-storey (Fig. 13B). However, geological mapping (repeated several times between 2013-2018), together with facies analysis and borehole studies, made it possible to partially reconstruct the channel patterns in plan view (Fig. 14). The primary channel planform consists of an interconnected network of short (up to $0.5 \mathrm{~km}$ ), relatively narrow (up to $50 \mathrm{~m}$ ), straight to sinuous reaches, which were separated by islands of strongly cohesive overbank muds. Thus, the palaeoriver reaches merged and split around the muddy islands. The palaeoflow directions shown in Figure 14 were measured in the field.

\section{INTERPRETATION}

Interpretation of the palaeochannel pattern and palaeoriver type has been limited mainly to the lignite-bearing areas belonging to the Konin Lignite Mine. These areas occupied shallow tectonic depressions, where the muddy succession with palaeochannels lies above the lignite seam. The primary channels were characterized by vertical infill, because the average aspect ratio (w/t) was $<15$ due to cohesive muddy banks (e.g., Widera et al., 2019). However, interpreting a river pattern (i.e., in the geological record) in plan view is difficult and not necessarily conclusive about its anastomosing nature (Fig. 14), as there is never any certainty that the mapped primary channels existed at that same time. By contrast, the secondary channels were slightly meandering as indicated by $w / t$ values in the range of 15-30 (Zieliński and Widera, 2020). The variety of in-channel facies, with a significant content of sandy-muddy and muddy facies, shows that these were deposited over the long-term in a low to extremely low-energy fluvial environment. Therefore, taking into account the characteristics described above, the fluvial system studied may be considered as typical of an anastomosing river. Simply put, these channel and overbank deposits met most of the criteria specified for anastomosing rivers (e.g., Smith and Smith, 1980; Nadon, 1994; Makaske, 2001; Gibling, 2006; North et al., 2007; Zieliński, 2014; and other references therein).

\section{MODERN SAND- TO MUD-DOMINATED ANALOGUES}

In general, the late Neogene anastomosing river system studied is mud-dominated, because it contains $>95 \mathrm{vol} . \%$ of 
Sedimentological characteristics of the in-channel and overbank facies typical of the late Neogene anastomosing fluvial system in the Konin area, central Poland (modified from Maciaszek et al., 2019; Widera et al., 2019; Zieliński and Widera, 2020)

\begin{tabular}{|c|c|c|c|}
\hline Facies & Code & Description & Interpretation \\
\hline \multicolumn{4}{|c|}{ In-channel facies } \\
\hline $\begin{array}{l}\text { Sand, coaly sand } \\
\text { and muddy sand with } \\
\text { a trough cross-strati- } \\
\text { fication }\end{array}$ & $\begin{array}{l}\text { St, SCt, } \\
\text { SMt }\end{array}$ & $\begin{array}{l}\text { Very common in the deepest parts of the } \\
\text { main channel; individual set up to } 0.4 \mathrm{~m} \text {, } \\
\text { while co-set up to } 1 \mathrm{~m} \text {; evidently erosional, } \\
\text { concave-up bases; presence of mud balls } \\
\text { and xylites }\end{array}$ & $\begin{array}{l}\text { Predominantly tractional deposition as 3D dunes; } \\
\text { upper part of lower flow regime; mud balls derived } \\
\text { from channel banks; xylites derived from the un- } \\
\text { derlying lignite seam }\end{array}$ \\
\hline $\begin{array}{l}\text { Sand, mud, sandy } \\
\text { mud and silty sand } \\
\text { with a trough } \\
\text { cross-stratification }\end{array}$ & $\begin{array}{c}\text { St, } \\
\text { STt } \\
\text { STt }\end{array}$ & $\begin{array}{l}\text { Present only in the secondary channels; } \\
\text { sandy and muddy facies sandwiched; indi- } \\
\text { vidual set up to } 0.4 \mathrm{~m} \text {; co-set up to } 3 \mathrm{~m}\end{array}$ & $\begin{array}{l}\text { Deposition mainly from traction; suspension possi- } \\
\text { ble; lower part of lower flow regime }\end{array}$ \\
\hline $\begin{array}{l}\text { Sand with a planar } \\
\text { cross-stratification }\end{array}$ & Sp & $\begin{array}{l}\text { Situated in the deepest parts of the primary } \\
\text { channel; mainly individual sets up to } 0.4 \mathrm{~m} \text {; } \\
\text { co-sets occasional; erosional, flat bases }\end{array}$ & $\begin{array}{c}\text { Tractional deposition as 2D dunes; upper part of } \\
\text { lower flow regime }\end{array}$ \\
\hline $\begin{array}{l}\text { Horizontally } \\
\text { (plane-parallel) strati- } \\
\text { fied sand, coaly sand } \\
\text { and muddy sand }\end{array}$ & $\begin{array}{l}\text { Sh, SCh, } \\
\text { SMh }\end{array}$ & $\begin{array}{l}\text { Located mainly in the deepest parts of the } \\
\text { primary channel; often between other } \\
\text { large-scale cross-stratified facies; only indi- } \\
\text { vidual sets up to } 0.2 \mathrm{~m} \text {; bases and tops ero- } \\
\text { sional, but bases flat }\end{array}$ & $\begin{array}{l}\text { Bedload transport; upper flow regime; flow condi- } \\
\text { tion transitional between those for the formation of } \\
\text { ripples and dunes }\end{array}$ \\
\hline $\begin{array}{l}\text { Horizontally } \\
\text { (plane-parallel) strati- } \\
\text { fied sand, muddy } \\
\text { sand and mud or } \\
\text { massive mud }\end{array}$ & $\begin{array}{l}\text { Sh, SMh, } \\
\text { Mh, Mm }\end{array}$ & $\begin{array}{l}\text { Predominate in the middle and upper parts } \\
\text { of the primary channel; often ends the sec- } \\
\text { ondary channels; sandy and muddy facies } \\
\text { sandwiched; individual set from millimetres } \\
\text { to } 0.2 \mathrm{~m} \text {, while co-set up to } 4 \mathrm{~m}\end{array}$ & $\begin{array}{l}\text { Deposition from traction and suspension in vari- } \\
\text { ous proportions; lowermost part of lower flow re- } \\
\text { gime; phases of waning flows when mud-laden } \\
\text { overbank waters drained back to the channel }\end{array}$ \\
\hline $\begin{array}{l}\text { Sand and silty sand } \\
\text { with ripple or climb- } \\
\text { ing-ripple cross-lami- } \\
\text { nation }\end{array}$ & $\begin{array}{l}\text { Sr, STr, } \\
\text { Src, STrc }\end{array}$ & $\begin{array}{l}\text { Present in all parts of both primary and sec- } \\
\text { ondary channels; individual sets up to } \\
0.05 \mathrm{~m} \text {, while co-sets up to } 0.3 \mathrm{~m}\end{array}$ & $\begin{array}{c}\text { Predominantly tractional deposition by bedload } \\
\text { transport as current ripples; lower part of lower } \\
\text { flow regime; additional deposition from suspension } \\
\text { as climbing ripples (type A) }\end{array}$ \\
\hline $\begin{array}{l}\text { Sand with flaser, } \\
\text { wavy and lenticular } \\
\text { (nodular) bedding } \\
\text { (heterolithic bedding) }\end{array}$ & Sf, Sw, Sn & $\begin{array}{l}\text { Located in some parts of secondary chan- } \\
\text { nels; these facies form upward fining succes- } \\
\text { sion from flaser, through wavy to lenticular } \\
\text { (nodular) bedding; sand content decreases } \\
\text { upwards, while mud content increases up- } \\
\text { wards; often capped by clayey-silty facies }\end{array}$ & $\begin{array}{l}\text { Water flow slow, but alternately decreases and in- } \\
\text { creases; sandy layers (ripples) are created during } \\
\text { relatively fast flow (<0.5 m/s), while muddy layers } \\
\text { are formed atop the ripples in intervals of very low } \\
\text { to almost stagnant water; lowermost part of lower } \\
\text { flow regime }\end{array}$ \\
\hline $\begin{array}{l}\text { Massive silty clay or } \\
\text { horizontally lami- } \\
\text { nated silt and coaly } \\
\text { silt }\end{array}$ & $\begin{array}{l}\text { YTm, Th, } \\
\text { TCh }\end{array}$ & $\begin{array}{c}\text { Present in various parts of the channels; end } \\
\text { sedimentary cycle in the primary channel or } \\
\text { end filling the secondary channel where } \\
\text { cover heterolithic bedding }\end{array}$ & $\begin{array}{c}\text { Deposition predominantly from suspension during } \\
\text { extremely low to almost stagnant water stages; } \\
\text { weak flow took place occasionally creating hori- } \\
\text { zontal lamination }\end{array}$ \\
\hline \multicolumn{4}{|c|}{ Overbank facies } \\
\hline $\begin{array}{l}\text { Massive mud or hori- } \\
\text { zontally stratified } \\
\text { mud }\end{array}$ & $\mathrm{Mm}, \mathrm{Mh}$ & $\begin{array}{l}\text { Cover >95 vol. \% of overbank deposits; vari- } \\
\text { ous colours from dark blue to blood red with } \\
\text { dark grey/black intercalations; 'warmer' } \\
\text { colours prevail upwards the muddy succes- } \\
\text { sion }\end{array}$ & $\begin{array}{c}\text { Predominantly deposition from suspension with } \\
\text { traces of traction in overbank area during floods; } \\
\text { strongly weathered and modified pedogenically } \\
\text { (various colours, palaeosols, lignites) }\end{array}$ \\
\hline $\begin{array}{l}\text { Coaly (carbona- } \\
\text { ceous) mud }\end{array}$ & $\mathrm{MCm}$ & $\begin{array}{c}\text { Present at different stratigraphical levels; } \\
\text { from a few to } 100 \text { s m long and up to } 2 \mathrm{~m} \\
\text { thick; lignite layer occasionally ends this fa- } \\
\text { cies }\end{array}$ & $\begin{array}{l}\text { Hydromorphic palaeosol horizon; muddy deposits } \\
\text { modified pedogenically; palaeosol developed in } \\
\text { poorly drained parts of the floodplain }\end{array}$ \\
\hline Massive coal (lignite) & $\mathrm{Cm}$ & $\begin{array}{c}\text { Located atop the palaeosol profile; individual } \\
\text { layer up to } 100 \mathrm{~s} \mathrm{~m} \text { long and up to } 0.2 \mathrm{~m} \\
\text { thick; contains }>50 \mathrm{wt} . \% \text { of organic matter } \\
\text { (i.e., }<50 \text { wt. } \% \text { of ash) }\end{array}$ & $\begin{array}{l}\text { Long-lasting development of hydromorphic } \\
\text { palaeosol with high groundwater level; favourable } \\
\text { conditions for fossilisation of plant debris; uninter- } \\
\text { rupted deposition by floods }\end{array}$ \\
\hline
\end{tabular}

overbank mud (cf. Figs. $2 \mathrm{~B}$ and 12 ) in relation to $<5$ vol. $\%$ of channel-fill deposits, which include fine sand and mud in various proportions (cf. Figs. 2 and 9-11). The muddy succession analysed, as noted above, was deposited in tectonically active areas after the Mid-Miocene Climatic Optimum when the climate became cooler and drier (e.g., Utescher et al., 2000; Zachos et al., 2001; Kasiński and Słodkowska, 2016; Słodkowska and Kasiński, 2016; Ivanov and Worobiec, 2017; Słodkowska and Widera, 2021; Widera et al., 2021a, b). At a time when the climate was still relatively warm and humid, sand-dominated channels were formed. Over time, as the climate cooled and became drier, the channel-fills became first sand-dominated, then sandy-muddy to mud-dominated (cf. Figs. 2B and 9).

It is difficult to look for one modern analogue for the entire late Neogene anastomosing river system in central Poland, as in the lower part of the sedimentary succession the channel-fills studied are more sand-dominated, while being more mud-dominated in their upper part. An analogous fluvial system should be characterized by similar channel and overbank sediments, as well as having developed in similar tectonic and climatic settings. In addition, the cause of river channel stabilisation (cohesion and/or vegetation) should be the same. Thus, we were unable to identify an appropriate modern analogue for the sand-dominated channels (cf. Figs. 2 and 9A, B) with muddy overbank deposits where the channel banks were stabilised by cohesion. So far, we have not found any evidence for the stabilisation of the channel banks by vegetation (perhaps because of its complete decay), which can be decisive in both ancient (e.g., Davies and Gibling, 2011, 2013; lelpi et al., 2015; Davies et al., 2020) and modern environments (e.g., Smith and Smith, 1980; McCarthy et al., 1991, 1992; Gradziński et al., 2000, 2003a, b). 

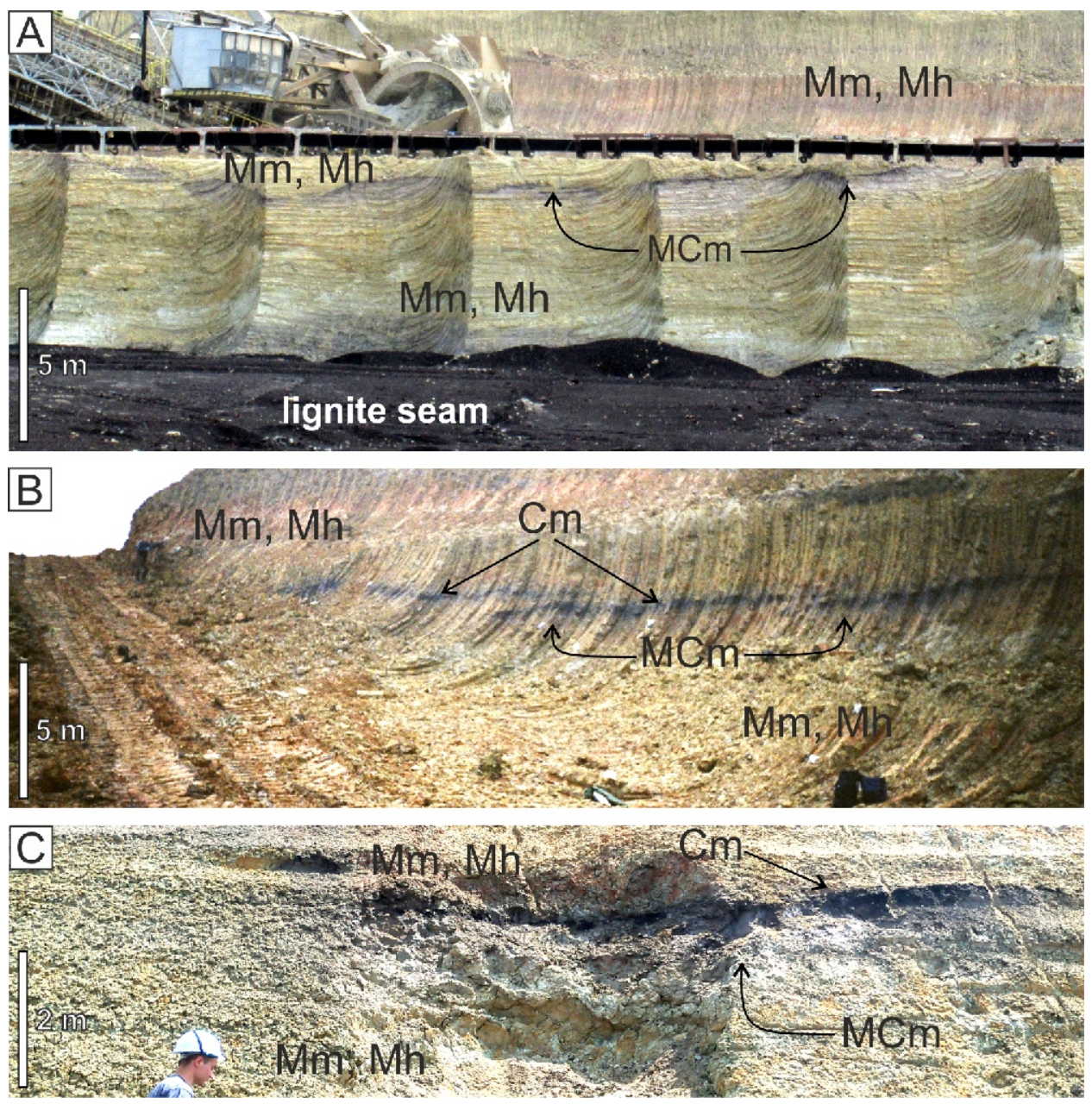

Fig. 12. Varicoloured overbank muds with traces of pedogenic modification

A - overbank deposits at the Jóźwin IIB lignite opencast (2016), note the clearly visible humus and leaching levels; B - overbank deposits at the Kazimierz North lignite opencast (2004), note a relatively long and thin (up to $20 \mathrm{~cm}$ ) lignite layer - $\mathrm{Cm}$; C - overbank deposits at the Jóźwin IIB lignite opencast (2013); note the well-developed profile of a hydromorphic palaeosol $-\mathrm{Cm}$ and $\mathrm{MCm}$; see Table 1 for facies codes

However, there are several other examples of sand-dominated channels encased in floodplain muds in the rock record (e.g., Uba et al., 2005; Botfalvai et al., 2016). In both cases, they developed in subsiding basins, when the climate was rather humid than dry.

In contrast to rivers with sand-dominated channels, it is possible to identify several modern river analogues with channel deposits that change from sandy-muddy to muddy. As noted above for this example, the climate grew colder, and most of all drier, over time. Then, the proportions of mud within the channel facies gradually increased. Thus, first the sandy-muddy fillings of the channel were formed (cf. Figs. 2, 9C, D, 10 and 11), that finally became mud-dominated (cf. Figs. 2 and 9E, F). In the case of sandy-muddy channels, it seems that the most closely related modern analogue is the Lachlan River (SE Australia) flowing from a temperate and relatively humid highland to a semi-arid low-gradient floodplain. Along with the course of the river, the bed-load sediments contain an increasingly smaller sand fraction and the mud content increases to $\sim 30 \mathrm{vol} . \%$ (Kemp, 2010), which is similar to most of the sandy-muddy channels studied (Widera et al., 2019; Zieliński and Widera, 2020). In the latter case, namely mud-dominated channels, the present-day analogues are those existing in arid climates, for example, in the Great Plains (central-western USA) and the Lake Eyre Basin (central-southern Australia). They are the anastomosing systems of Red Creek (Schumann, 1989) or Cooper Creek and the Diamantina River, respectively (e.g., Rust, 1981; Gibling et al., 1998; Tooth, 2000; Fagan and Nanson, 2004).

\section{HOLOCENE ANASTOMOSING RIVER}

GENERAL CHARACTERISTICS OF THE HOLOCENE DEPOSITS

The anastomosing system of the present day upper Narew River nowadays consists of a reach $\sim 35 \mathrm{~km}$ long between Suraż town and Rzędziany village (Fig. 15). The next similar downstream reach has been destroyed due to extensive drainage works related to agriculture. Thus, $\sim 110 \mathrm{~km}$ of the channels in length have been lost over the last 120 years (Marcinkowski et al., 2017), while their preserved parts currently constitute the Narew National Park. The valley of the multichannel reach is characterized by a flat bottom bounded by gentle slopes composed of Pleistocene glacial and fluvioglacial deposits that are up to 200 m thick (Bałuk, 1973; Banaszuk, 1996; Lindner and Astapova, 2000). This valley is relatively narrow (1-4 km), with 
A
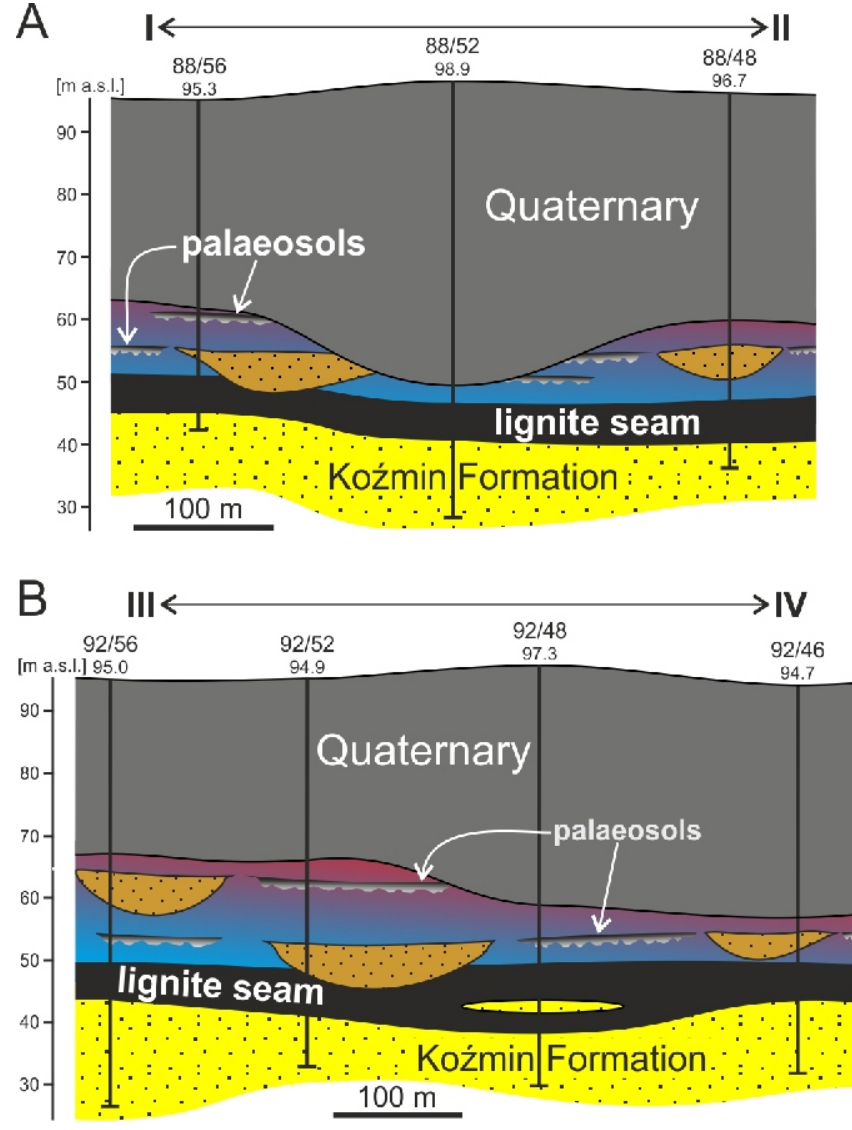

Fig. 13. Simplified cross-sections through palaeochannels and their close vicinity examined in the Jóźwin IIB lignite opencast (modified from Maciaszek et al., 2020)

A - cross-section I-II shows two sandy-muddy channels at the same stratigraphic level; B - cross-section III-IV depicts three sandy-muddy channels at two stratigraphic levels; see Figure 2 for other explanation and Figure 14 for the location of the cross-section lines

a low longitudinal gradient of $\sim 0.22 \mathrm{~m} / \mathrm{km}$ (Gradziński et al., 2000). The origin of the valley remains unclear, but is probably related to slow-melting dead ice calved from an ice-sheet in the Pleistocene. Nonetheless, the Narew valley is filled with late Pleistocene/early Holocene sands (15-25 m thick) regarded as being older, pre-anastomosing fluvial deposits (Okruszko and Oświt, 1973), and peat cover of Holocene age (Churski, 1973; Banaszuk, 1996).

The calculation made for the 28 channels of the anastomosing system show that they are characterized by a 2-10 width/depth ratio with sinuosity index $<1.3$ (Gradziński et al., 2003a), and anabranching index at 4.1 (Marcinkowski et al., 2018). The majority of the channels are straight, and tight bends occur only occasionally with no distinct scroll-bar topography (Figs. 16 and 17). The longer reaches of higher sinuosity occur usually together with oxbow lakes. Locally, the abandoned channels are preserved and separated from active ones partially or completely by plant jams and subsequent dense vegetation cover. The channels are relatively narrow, up to $35 \mathrm{~m}(5-35 \mathrm{~m})$ and their depth does not exceed $6 \mathrm{~m}(3-6 \mathrm{~m})$

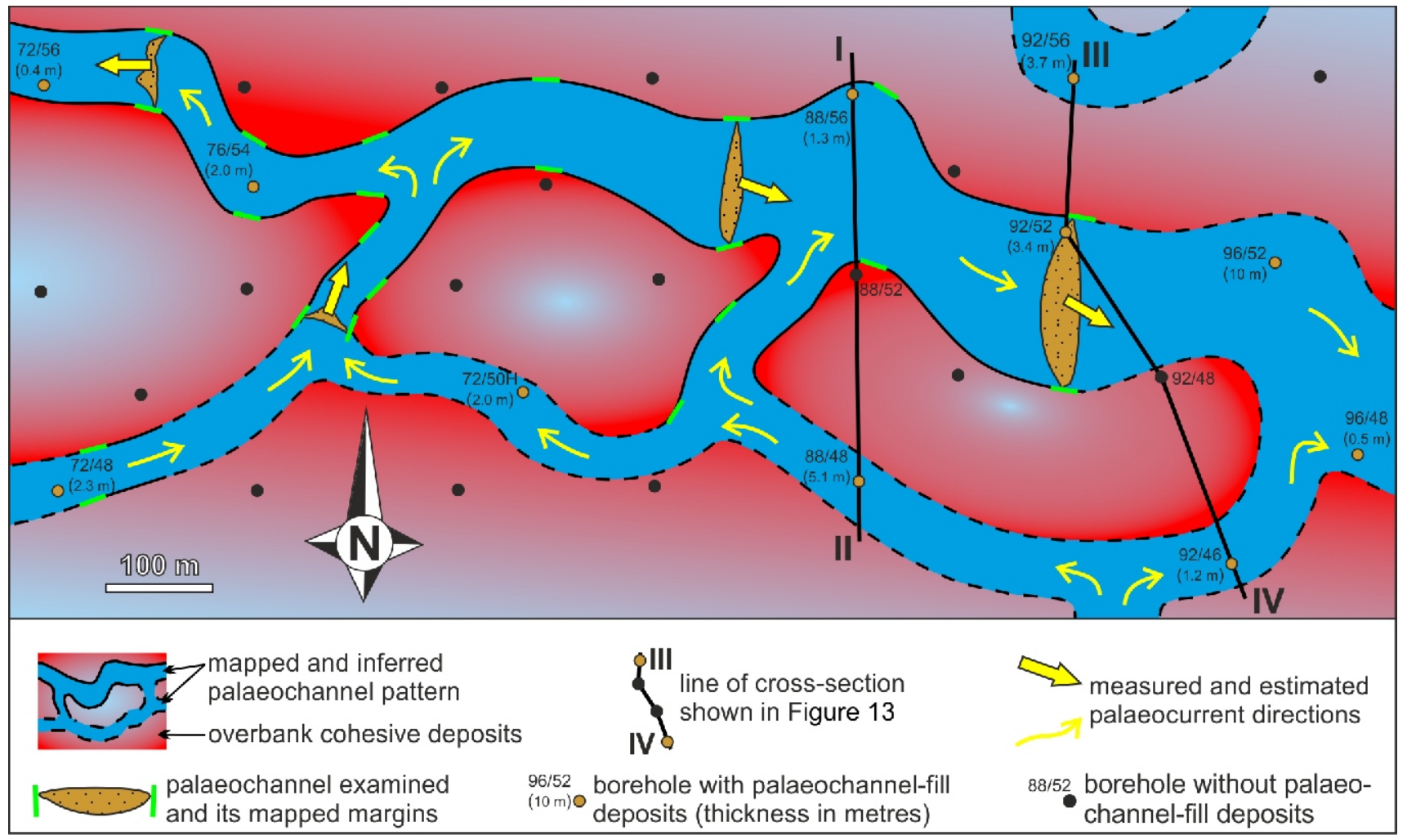

Fig. 14. Mapped and inferred palaeochannel pattern of the southeastern part of the Jóźwin IIB lignite opencast (modified from Widera et al., 2019; Maciaszek et al., 2020)

Note that the multi-channel river system generally flows northwards, i.e., in line with the orientation of the tectonic graben; cross-section I-II and III-IV are given in Figure 13 


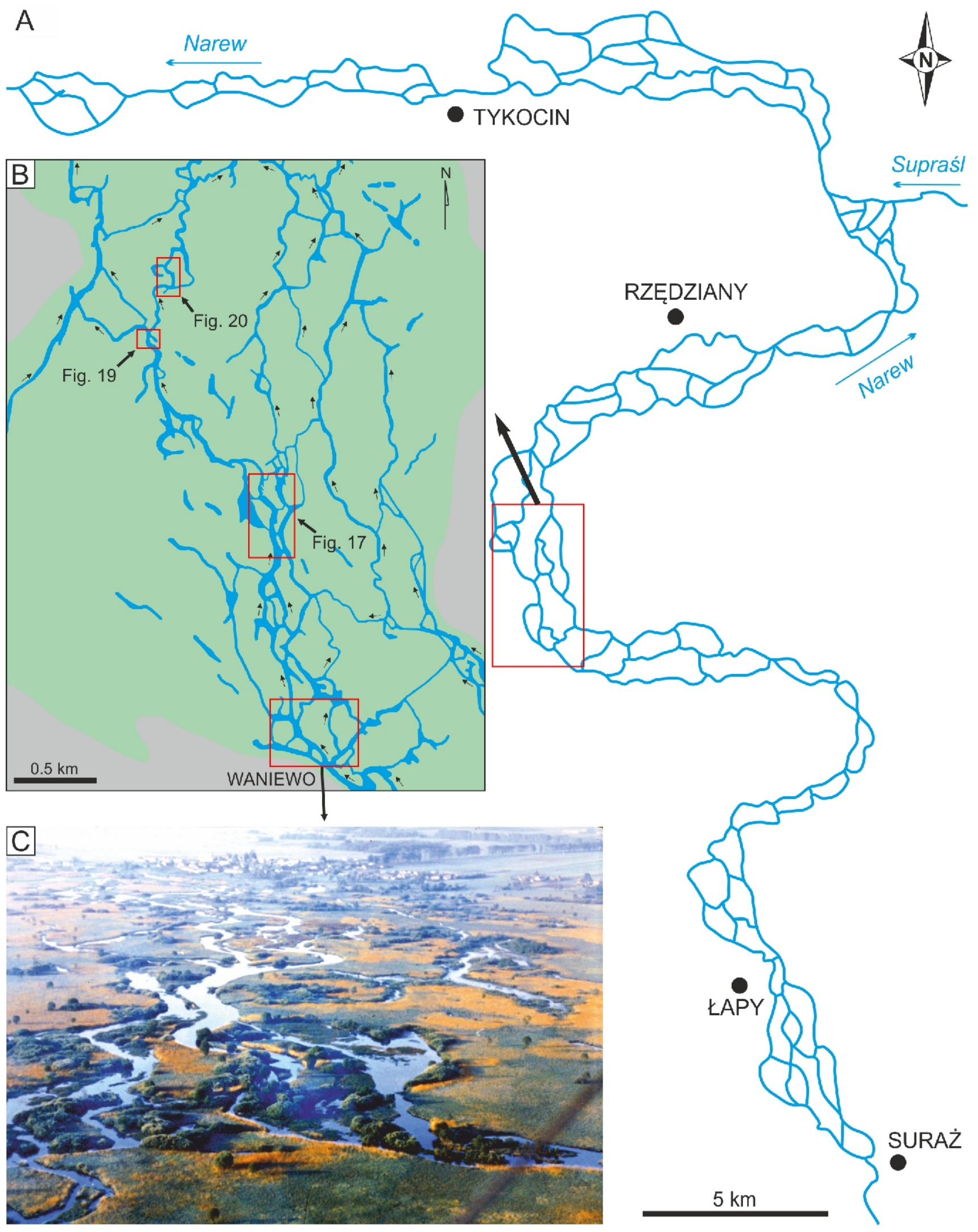

Fig. 15. The upper Narew River anastomosing system

A - reach between the towns of Suraż and Tykocin; the downstream part from Rzędziany shows as it looked before the drainage works in the 20th century; B - middle part of the Narew River valley; in grey - hills bordering the valley, in green - overbank areas; C - aerial view towards the village of Waniewo 


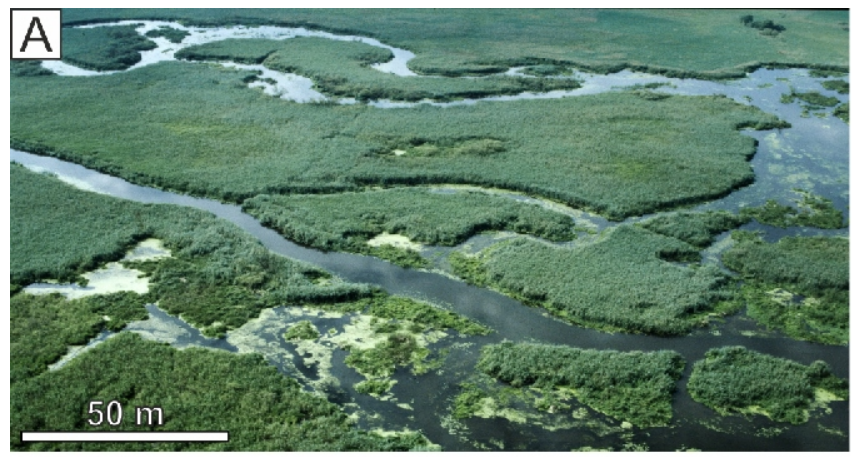

C

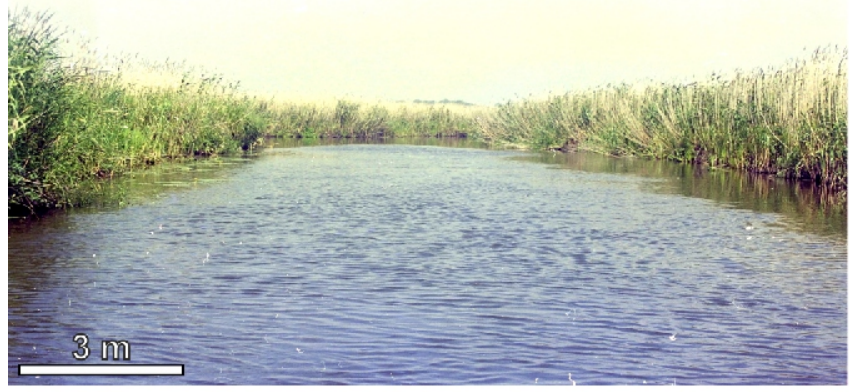

E

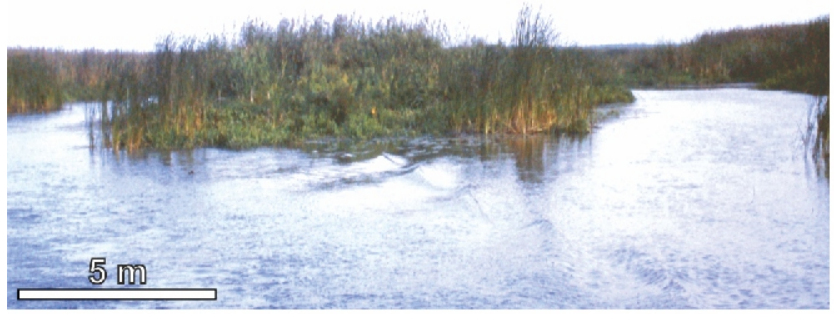

peat clasts

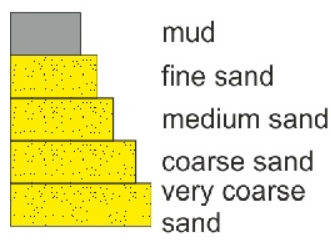

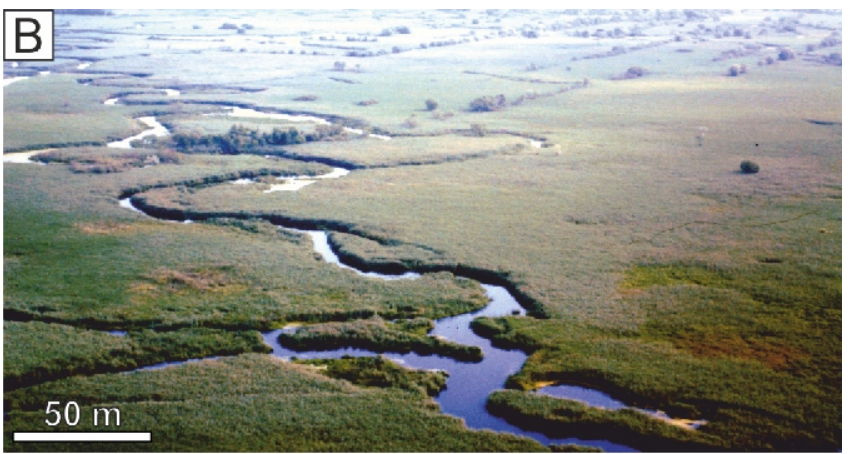

D
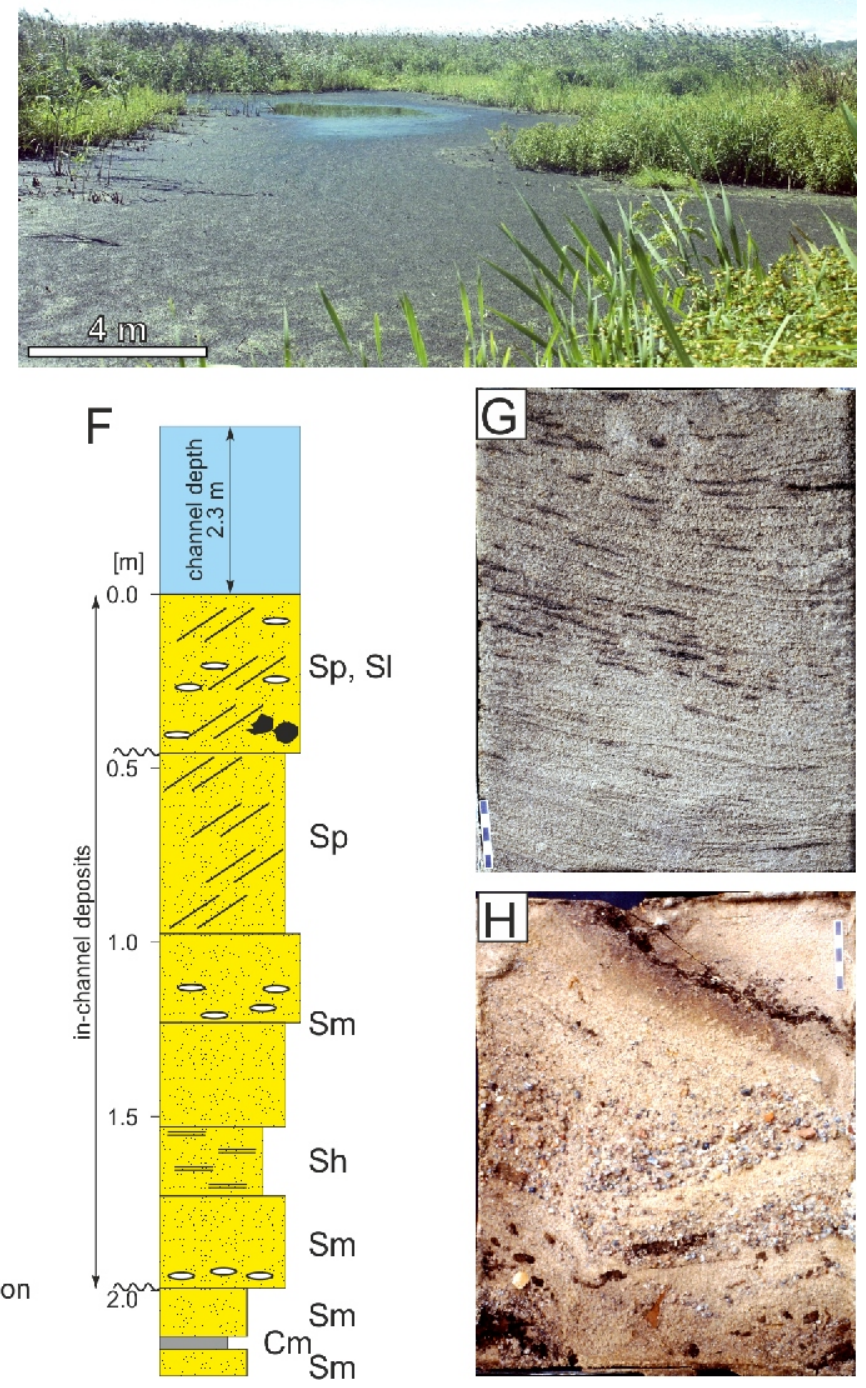
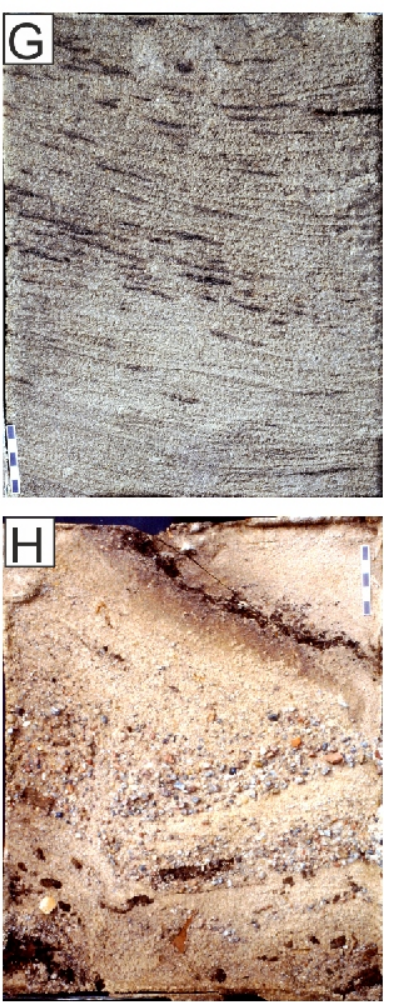

\section{Fig. 16. Various channel planforms}

A - straight and sinuous reaches of the Narew River; B - inherited meandering-type channel morphology, note densely vegetated interchannel area; $\mathbf{C}$ - straight reach of the main channel; $\mathbf{D}$ - abandoned channel; $\mathbf{E}$ - mid-channel bar in the main channel; $\mathbf{F}$ - lithological log of the in-channel deposits (upper $2 \mathrm{~m}$ ), as well as older sands and peat (lowermost $25 \mathrm{~cm}$ ); $\mathbf{G}$ - low-angle cross-bedding (SI facies) from the lower part of the point bar, note dark laminae enriched in plant detritus; $\mathbf{H}$ - thalweg deposits, note gravel-sized particles; see Table 1 for facies code; G, $\mathbf{H}$ - lacquer peel samples 


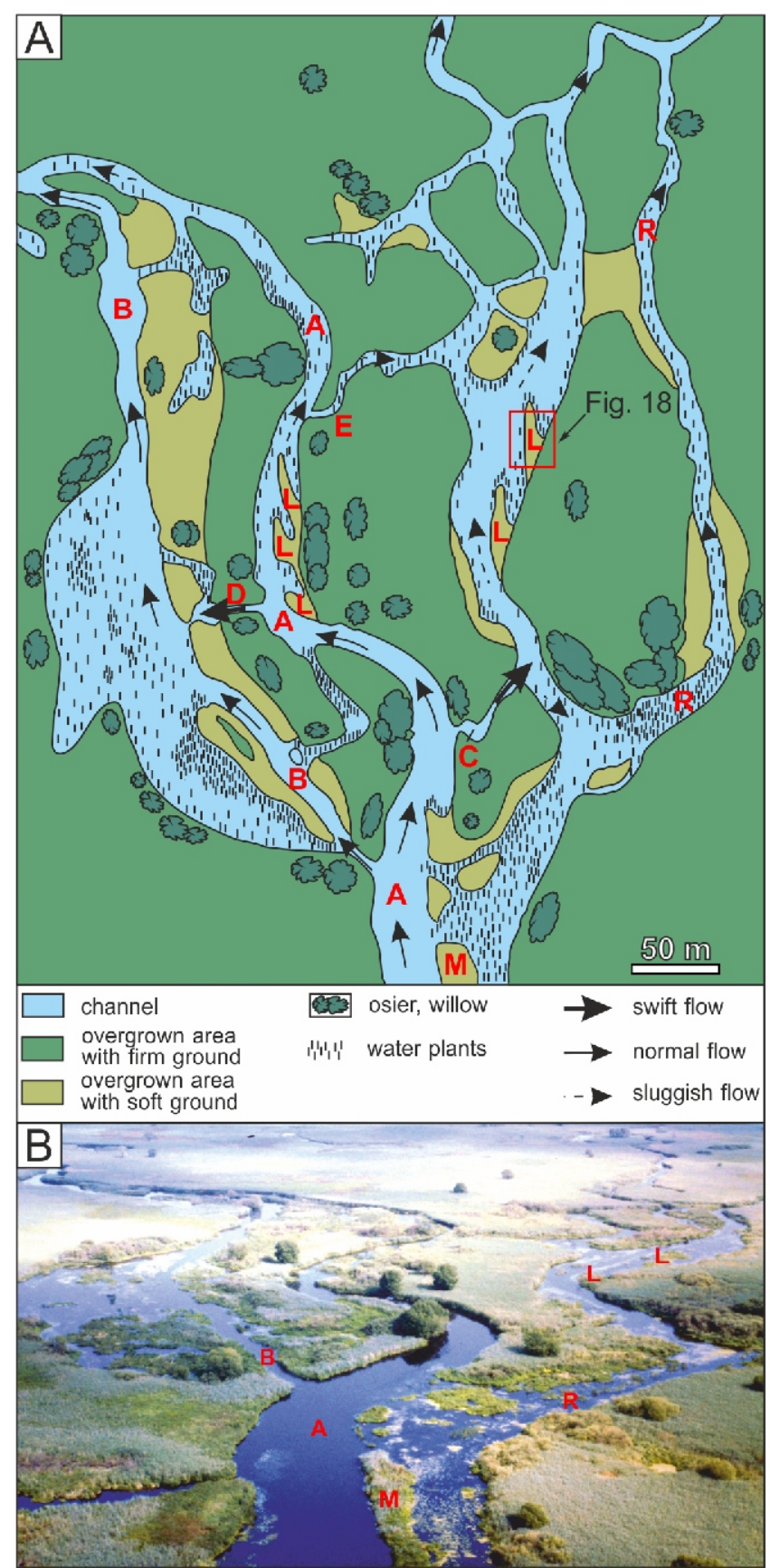

Fig. 17. Fragment of a dense channel network (for location see Figure 15)

A - A-E and R - river channels, $L$ - vegetated linguoid bars shown in detail in Figure 18, M - mid-channel bars; B - aerial view of the same area

with a course generally parallel to the valley margins. The flow velocity in the main channels changes from 10 to $30 \mathrm{~cm} \cdot \mathrm{s}^{-1}$ at low-water stage; however, during normal-water stage, it attains speeds of up to $70 \mathrm{~cm} \cdot \mathrm{s}^{-1}$.

The channel banks are predominantly steep, while the channels are box-shaped in cross-sectional view, with flat bottoms. The asymmetry of the channels is only seen on their convex sides. Typically, active channels lack natural levees composed of clastic sediments. The overbank areas are usually flat, except those parts with inherited pre-fluvial small hills that are

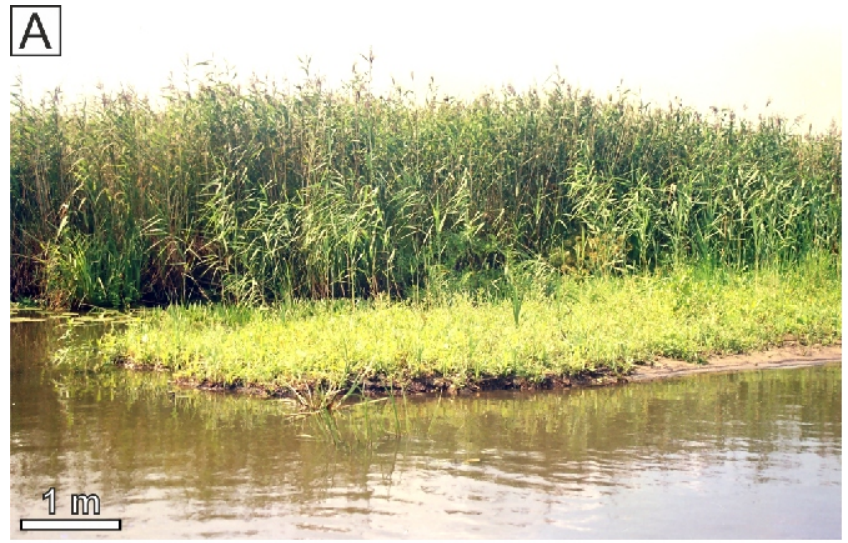

B
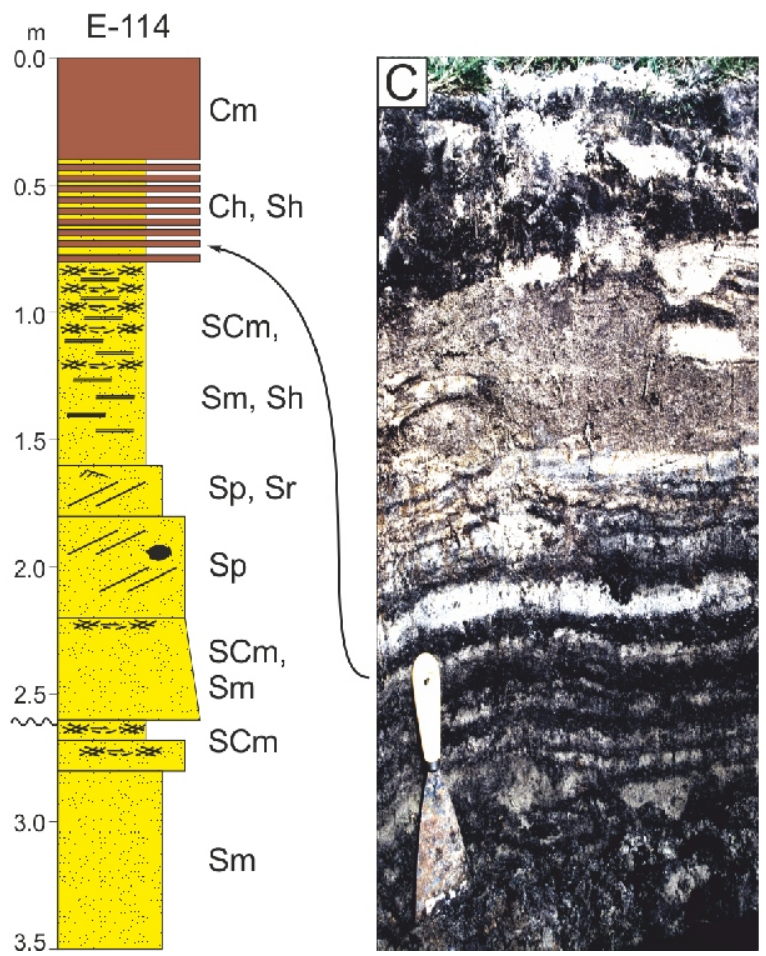

Fig. 18. Linguoid bar (for location see Figures 17A, 19E)

A - view of the bar top during extremely low-water stage; B linguoid bar depositional sequence; C - heterolithic association composed of organic-rich sand or peat-like deposits; see Figure 20 for other explanation and Table 1 for facies code

relicts of older deposits preserved inside the Narew valley. Moreover, the overbank areas (including mid-channel islands) are densely vegetated by peat-forming plants, mainly rushes and reeds (Figs. 17-21). The floodplain is usually inundated once a year during the spring due to snow melting. Over the period from July to October a low-water stage prevails. However, some parts of the Narew floodplain even at that time are water-saturated and therefore accessible only when they are frozen.

\section{DESCRIPTION OF CHANNEL FACIES}

The anastomosing system of the upper Narew River is characterized by sandy bedload. The suspended load, consisting of finer grains and abundant dispersed organic matter, is almost negligible. The sand material carried within active channels varies in grain size. It is moderately sorted, mostly medium- to 

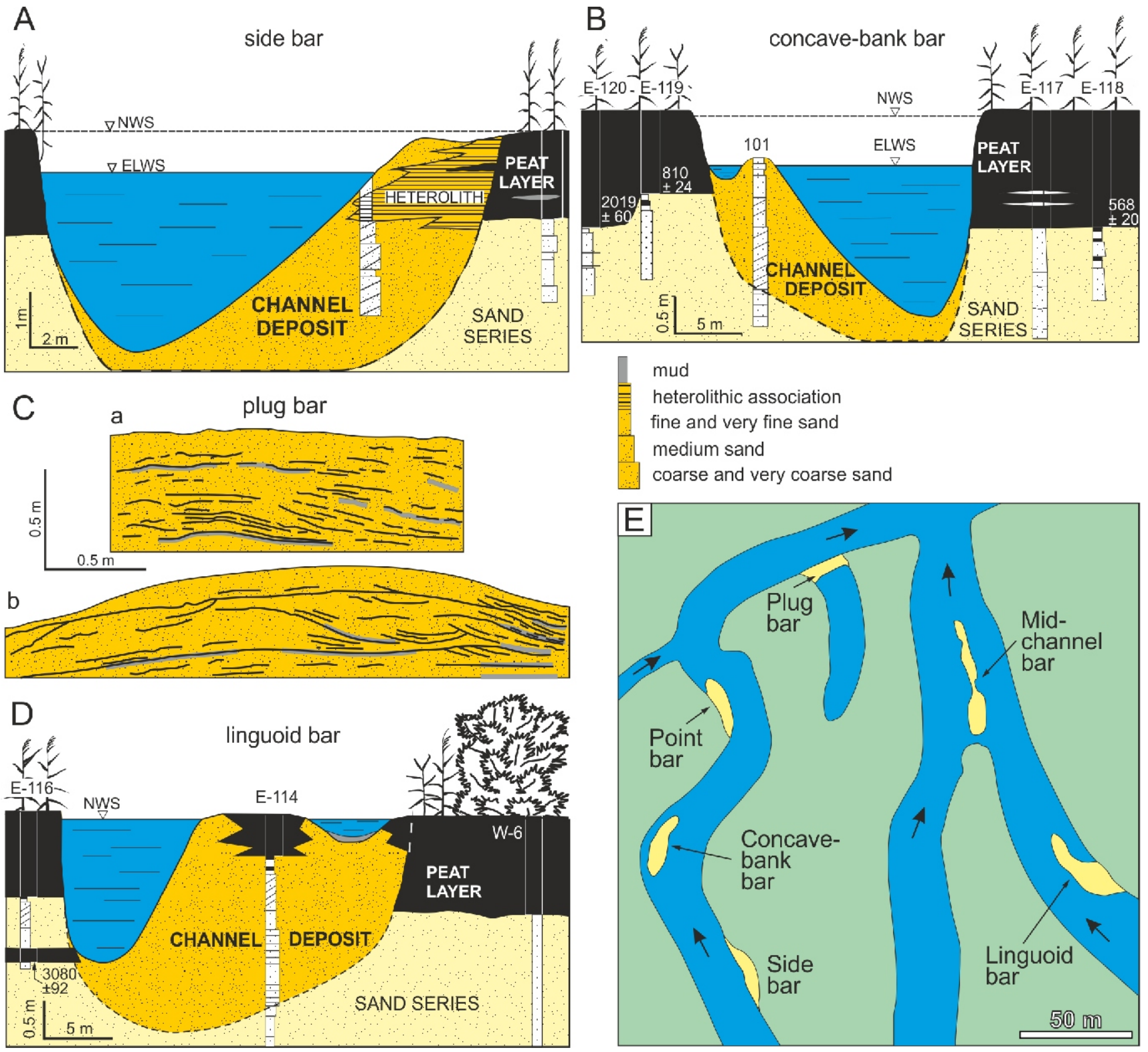

Fig. 19. Accretionary macroforms of the upper Narew River anastomosing system

A - side bar; B - concave-bank bar; C - plug bar top (exposed during extremely low-water stage), a) excavation perpendicular to flow direction, b) excavation parallel to flow direction; D - linguoid bar; $\mathbf{E}$ - location of some types of bars within the river channels; for location of this area see Figure 15; NWS - normal-water stage, ELSW - extremely low-water stage

coarse-grained with granule-sized clasts admixed in some cases. Moreover, peat rip-up clasts measuring to tens of $\mathrm{cm}$ in size were rarely observed at the bottom of larger channels. The in-channel sands are usually horizontally laminated (Sh) or lacked mesoscopically visible sedimentary structures (Sm) within fine sand. In places, cross-bedding (St, SI, Sp) was noted as well as ripple ( $\mathrm{Sr}$ ) and flaser to wavy lamination (Sf, Sw; Table 4). The vertical succession of these facies was only observed in a few cases, that is, in places where the tops of channel bars were emergent even at low-water stage. Due to the relatively great depth of the channels, their bottom morphology was only examined by sounding and diver observations, as well as through a few borehole cores from channels shallower than $3 \mathrm{~m}$. In this way, on the basis of shape and position within the channels, several accretionary macroforms, termed as bars, have been distinguished: side, concave-bank, plug, point, linguoid, and mid-channel (Figs. 16-20).
INTERPRETATION

The first four macroforms (side, concave-bank, plug, point) are rare and characterized by relatively small (up to $10 \mathrm{~m}$ wide and up to $20 \mathrm{~m}$ long) dimensions, although they can occasionally reach $>10 \mathrm{~m}$ in width and $>30 \mathrm{~m}$ in length. The macroforms could only be observed during low-water stage when their upper parts are subaerially exposed. The tops of these bars are densely vegetated and covered by water during the normal-water stage. Therefore, the identification of the bars was only possible during low-water stage.

The linguoid and mid-channel bars (10-50 wide and up to $150 \mathrm{~m}$ long), could be recognised directly in the field or even on aerial photographs (Figs. 17 and 18A). The lower parts of all the bars are composed of sediments similar in grain size (very coarse to medium sand) to those accumulated in the deeper parts of the channels with horizontal and large-scale cross-bed- 


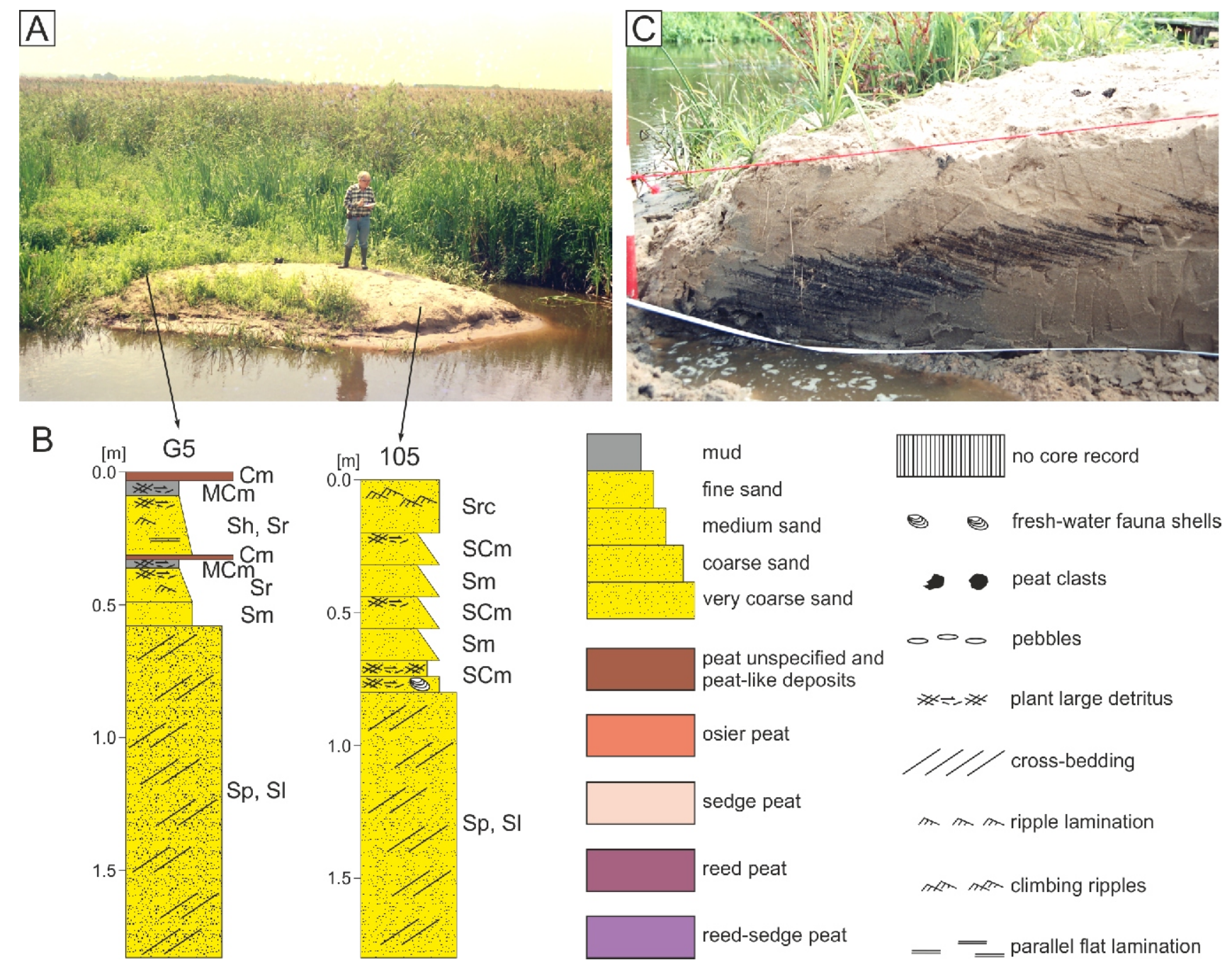

Fig. 20. Point bar (for location see Figure 19E)

A - exposed bar top during extremely low-water stage; Prof. R. Gradziński - leader of upper Narew River fluvial system studies, for scale; B - point bar depositional sequences; C - climbing ripples exposed in a trench perpendicular to the flow direction; see Table 1 for facies code

ding structures (Sh, St). However, fine sand alternating with dark, muddy, and organic-rich sand occurs in the upper parts. This alternation of rippled or wavy laminated sand $(\mathrm{Sr}, \mathrm{Sw})$ with massive dark sand (Sm) created a heterolithic facies association (Fig. 18B, C). The thickness of its individual sets was highly variable from a few $\mathrm{mm}$ up to several $\mathrm{cm}$. Rapid plant colonisation of the bars leads to their stabilisation and, as a result, to the formation of peat layers at the tops of these bars.

The mid-channel bars occur in straight reaches of wide channels, and their elongation is generally parallel to the channel margins (cf. Figs. 16E, 17 and 19E). These bars are often segmented by secondary depressions and elevations emerging even during the normal-water stage, which resemble a chain of narrow, vegetated islands. They are continuous macroforms only at low-water stage. The internal structure of the mid-channel bars seems to be similar to linguoid bars, that is, with sands at the base and heterolithic sediments (organic-rich mud, muddy sand, sand), sand and/or peat at the top.

Typical side bars occur in the local embayments of the straight reaches and are attached to the channel margin
(Fig. 19A, E). Concave-bank bars are located on bends, close to the outer river banks. Additionally, they are separated from the channel margin by shallow depressions that are filled with water during the normal-water stage. This type of bar shows a fining-upwards sequence starting with cross-bedded mediumto coarse-grained sand replaced towards the top by horizontally and ripple laminated fine sands (Fig. 19B). The plug bars, which terminate the abandoned channels, are permanently submerged and exposed only during extremely low-water stages (Fig. 19C, E). Their upper parts consist of fine and well-sorted sand, which is characterized by rippled (with climbing ripples), horizontal, and wavy lamination.

The rarest accretionary macroform comprises point bars, the deposits of which create a fining upwards succession with cross-stratified, well-sorted, and ripple laminated fine- to medium-grained sand at the base (Figs. 19E and 20). The uppermost parts of the bar tops are built of current or climbing ripples, organic mud, and peat (Fig. 20B, C). These sediments are strongly reworked by plants as shown by the presence of rhizomes and roots. The point bars are usually exposed during the extreme low-water stage. 


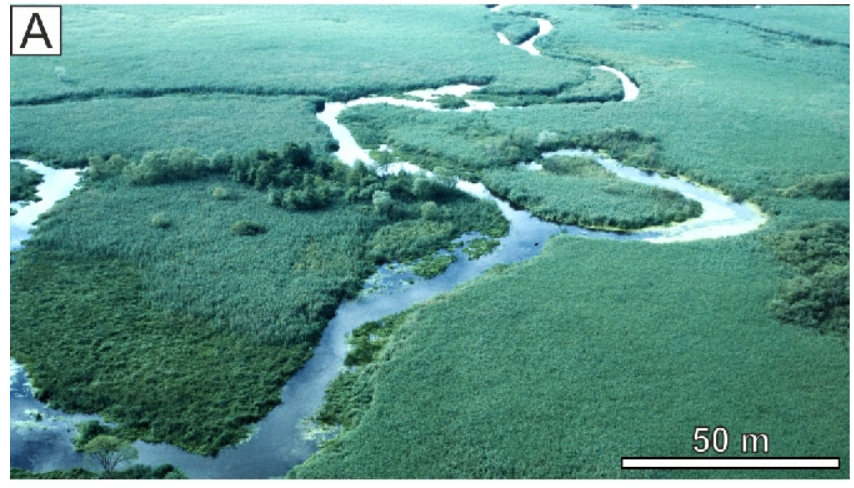

\section{C}

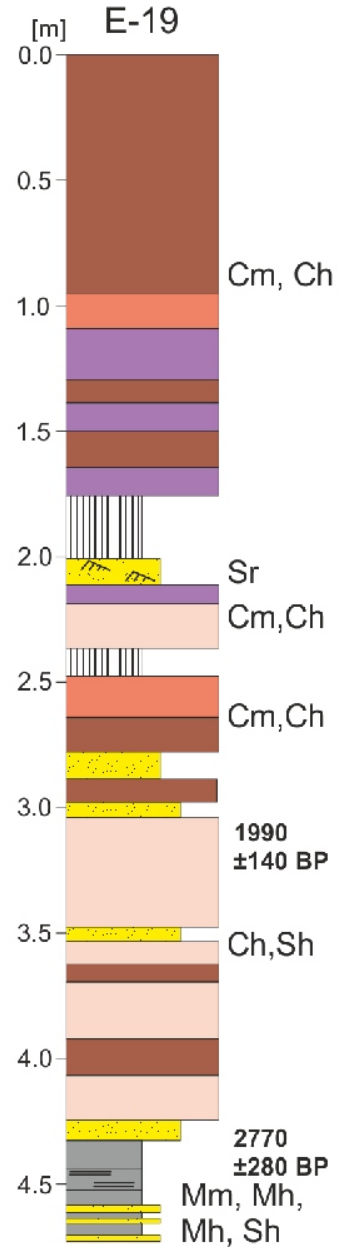

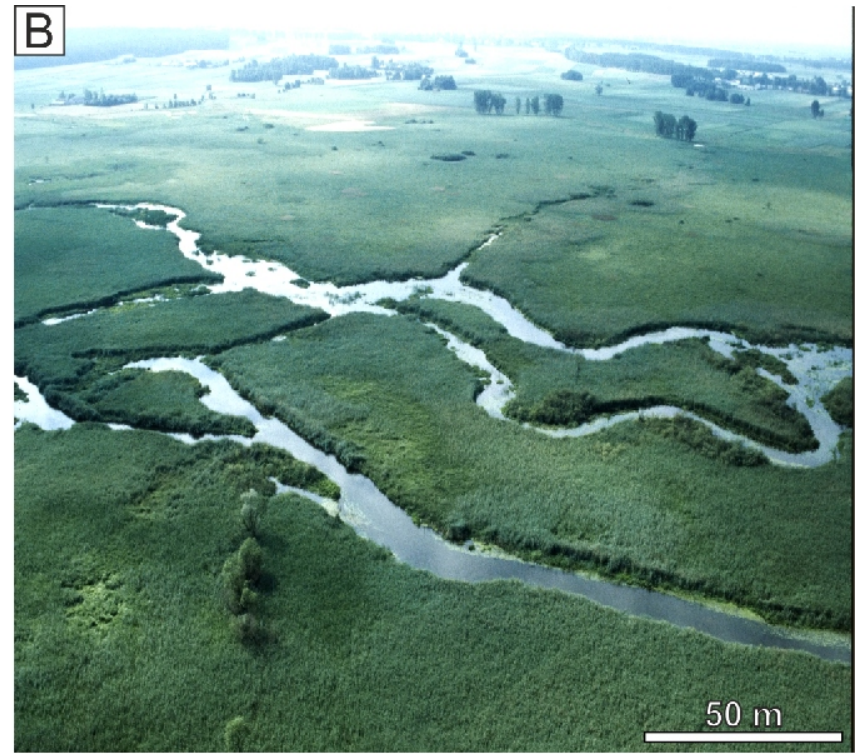
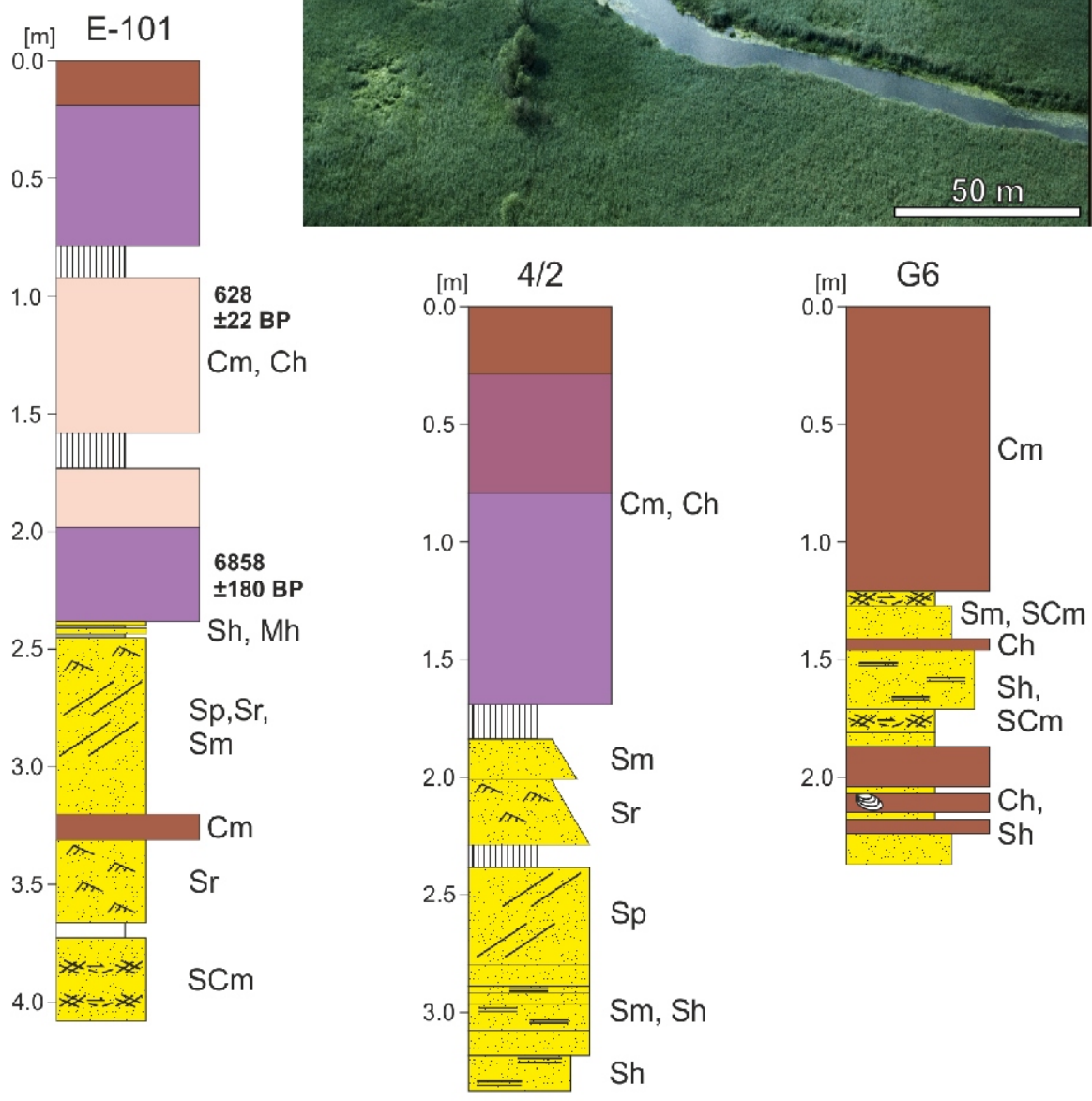

Fig. 21. Densely vegetated inter- and extrachannel areas

A, B - aerial view of stable islands and broad overbank area; C - lithology of the overbank deposits with ages of various peat generations; see Figure 20 for other explanation and Table 1 for facies code

DESCRIPTION OF OVERBANK FACIES

The overbank area comprises stable islands, separating individual channels, and other parts of the alluvial valley. During the high-water stage, the entire floodplain is covered by water, although when the water is at normal-water stage its surface is also waterlogged. At this time, the floodplain looks like a mosaic of small pools and clumps overgrown by aquatic and semiaquatic herbaceous plants (cf. Figs. 15C, 16A, B, 17 and $21 \mathrm{~A}, \mathrm{~B}$ ). Generally, the overbank area is flat, devoid of crevasse splays and natural levees. Only locally, low wedges (up to
$15 \mathrm{~cm}$ ), composed of loose reed fragments, can be observed along the channel banks. The floodplain is densely vegetated by well-rooted herbaceous peat-forming plants with almost negligible trees occurrence (Fig. 21A, B). Therefore, the entire area is covered by peat and peat-like sediments. In the latter case, they contain $>50 \mathrm{wt}$ \% of mineral matter. Similarly, the stratified peat, interbedded with siliciclastic sediments (sand, mud), is enriched with 9-50 wt.\% inorganic material (Gradziński et al., 2003b). Various types of peat have been recognised on the basis of their dominant plant group (see explanations in Fig. 20). They have been identified as sedge or reed peats, 
Sedimentological characteristics of the in-channel and overbank facies typical of the Holocene anastomosing fluvial system of the upper Narew River, northeastern Poland (modified from Gradziński et al., 2000, 2003a, b)

\begin{tabular}{|c|c|c|c|}
\hline Facies & Code & Description & Interpretation \\
\hline \multicolumn{4}{|c|}{ In-channel facies } \\
\hline Massive sand & $\mathrm{Sm}$ & $\begin{array}{l}\text { Coarse- to medium-grained, locally or- } \\
\text { ganic-rich fine-grained; granule-size particles } \\
\text { admixture; peat rip-up clasts; mostly at the } \\
\text { base of accretionary macroforms; if } \\
\text { fine-grained, occurs at bars top }\end{array}$ & $\begin{array}{c}\text { Episodes of a non-selective rapid deposition as- } \\
\text { cribed to peak-flow events, erosion of peat-com- } \\
\text { posed steep banks }\end{array}$ \\
\hline $\begin{array}{l}\text { Sand with } \\
\text { cross-stratifications }\end{array}$ & $\mathrm{Sp}, \mathrm{SI}, \mathrm{St}$ & $\begin{array}{l}\text { Medium- to coarse-grained sand occurring at } \\
\text { lower to middle part of the bars; } \\
\text { down-stream laminae inclination; distinction } \\
\text { between high- and low-angle, tabular and } \\
\text { trough or even horizontal stratification in } \\
\text { small-diameter core samples is generally dif- } \\
\text { ficult; some facies may have been } \\
\text { misclassified as Sh facies described below, } \\
\text { hence sands with either of these stratifica- } \\
\text { tion types lumped jointly into one lithofacies }\end{array}$ & $\begin{array}{l}\text { Sand transport and deposition in the form of sub- } \\
\text { aqueous dunes of the upper part of lower flow re- } \\
\text { gime bedforms or slightly higher flow power } \\
\text { corresponding to 3D dunes (trough cross-stratifi- } \\
\text { cation), relative to 2D dunes (planar cross-stratifi- } \\
\text { cation) }\end{array}$ \\
\hline $\begin{array}{l}\text { Sand with horizontal } \\
\text { (plane-parallel) lami- } \\
\text { nation }\end{array}$ & Sh & $\begin{array}{l}\text { Coarse- medium- to fine-grained sand, oc- } \\
\text { curring at lower, deepest part of the bars. In } \\
\text { a few cases in the upper part as a thin layers } \\
\text { of fine sand. Together with cross-stratified } \\
\text { lithofacies most common }\end{array}$ & $\begin{array}{l}\text { Plane-bed transport and deposition of sand in the } \\
\text { upper flow regime, may correspond to flood-peak } \\
\text { discharges; unless the flow is too shallow for the } \\
\text { development of dunes while its velocity is too high } \\
\text { for the formation of ripples }\end{array}$ \\
\hline $\begin{array}{l}\text { Sand with ripple or } \\
\text { climbing-ripple } \\
\text { cross-lamination }\end{array}$ & $\mathrm{Sr}$ & $\begin{array}{l}\text { Mainly medium and fine-grained sand, in } \\
\text { places of B-type of climbing-ripple struc- } \\
\text { tures; occur at the top of bars; lamination ac- } \\
\text { centuated by fine dark plant detritus or } \\
\text { darker streaks of sand; lee-sides inclined at } \\
\text { low angle away from the channel; the climb } \\
\text { angle } 5-20^{\circ} \text {; co-sets thickness up to } 30 \mathrm{~cm} \\
\end{array}$ & $\begin{array}{l}\text { Transport and deposition by currents in the lowest } \\
\text { part of lower flow regime. Muddy and organic-rich } \\
\text { inter-laminae and ripple drapes indicate a highly } \\
\text { pulsating, waning-waxing and generally weak } \\
\text { flow. Climbing ripples indicates a high rate of sedi- } \\
\text { ment suspension fall-out relative to the rate of rip- } \\
\text { ple migration }\end{array}$ \\
\hline $\begin{array}{l}\text { Sand with flaser and } \\
\text { wavy lamination }\end{array}$ & Sf, Sw & $\begin{array}{l}\text { Mainly fine-grained sand occurring at bars } \\
\text { top; gradational boundaries with ripple lami- } \\
\text { nated sand; dark layers composed of or- } \\
\text { ganic-rich muddy sand, rarely dark mud; } \\
\text { usually capped with sand-rich peat } \\
\end{array}$ & $\begin{array}{c}\text { Depositional conditions resemble those of } \mathrm{Sr} \\
\text { lithofacies, with a weak and highly fluctuating flow, } \\
\text { but with more pronounced episodes of flow slack- } \\
\text { ening }\end{array}$ \\
\hline \multicolumn{4}{|c|}{ Overbank facies } \\
\hline Massive mud & $\mathrm{Mm}$ & $\begin{array}{c}\text { Dark, organic-rich mud, up to } 10 \mathrm{~cm} \text { in thick- } \\
\text { ness; usually occur at the base of peat layer } \\
\text { or as member of sand/mud heterolithic asso- } \\
\text { ciation }\end{array}$ & $\begin{array}{l}\text { Predominantly deposition from suspension; } \\
\text { sand-devoid slack-water environment typical for } \\
\text { oxbow lakes of abandoned river channels; if oc- } \\
\text { curring at bars top represents deposition during } \\
\text { periods of flow cessation terminating main phase } \\
\text { of channel aggradation }\end{array}$ \\
\hline Peat & C & $\begin{array}{l}\text { Mainly sedge and reed peat, less abundant } \\
\text { mixed sedge-reed and osier peat; } \\
\text { phytogenic material accumulated on } \\
\text { overbank areas (including interchannel is- } \\
\text { lands); peat and peat-like layer up to } 4 \mathrm{~m} \text { in } \\
\text { thickness; } 9-50 \% \text { of dry mass of the mineral } \\
\text { matter content and }>50 \% \text { in peat-like depos- } \\
\text { its }\end{array}$ & $\begin{array}{l}\text { Growth of the peat-forming aquatic and } \\
\text { semiaquatic herbaceous plants; area covered by } \\
\text { water during high-water stage for many weeks; } \\
\text { variable input of fine-grained sand and mud some- } \\
\text { times relatively high as slack-water suspension }\end{array}$ \\
\hline
\end{tabular}

which are less abundant mixed sedge-reeds and osier peats with no consistent pattern to their vertical succession. The total thickness of peat in the overbank area is up to $4 \mathrm{~m}$, but in most cases does not exceed 1-2 m (Fig. 21C).

The substrate of the peat cover is morphologically and lithologically diverse over a short distance. Its base is composed of an upwards-fining sequence starting with medium- or coarse-grained sand with features described herein as in-channel deposits. On top of this unit are fine-grained sands with thin interbeds of peat-like sediments or gyttja, while a relatively thick (up to a few dm) organic-rich mud layer with sand intercalations occurs at the top. In a very few cases, the peat or peat-like sediments are directly underlain by in-channel sands. Most of the basal peat ages, obtained using the radiometric carbon dating method $\left({ }^{14} \mathrm{C}\right.$ ), are in the range of 3200-1340 BP (cf. Figs. 19B, $\mathrm{D}$ and $21 \mathrm{C})$.

\section{IINTERPRETATION}

The peat ages obtained from the study area can be interpreted as the beginning of the peat accumulation, mainly during the late Subboreal and the early Subatlantic intervals; however, deposition of peat in other parts of the Narew valley started at different times. Thus, the calculated long-term peat accretion rate varied from 0.16 to $2.37 \mathrm{~mm} /$ year, while its average value is $1.0-1.5 \mathrm{~mm} /$ year. These results are typical or even slightly higher than those obtained for other temperate peatlands (e.g., Gorham et al., 2003; Chimner and Ewel, 2005). The differences in the sedimentation rate can be explained by various proportions between peat and siliciclastic sediments, as well as by biomass production related to different plants and their susceptibility to compaction.

\section{CONTROLLING ROLE OF VEGETATION}

Vegetation has a major impact on the fluvial geometry of the upper Narew anastomosing system. The channel margins are densely overgrown with vegetation, forming reed belts that are up to several metres wide. They extend from the bottom of the channel and act like a sieve, slowing down the flow and facilitating the deposition of siliciclastic sediment, that is, sand, silt and clay particles. The rapid colonisation of the bar tops, at first by 
pioneer plant assemblages, may have been quickly replaced by well-rooted peat-forming vegetation typical of overbank areas The increasing vegetation density, especially in shoals between bars (concave-bank and linguoid) and bank margins, caused the cessation of additional flow (cf. Figs. 17 and 18B, D, E). During the final stage, the bar tops lose their individuality and become incorporated into the overbank area. The development of the in-channel macroforms, stabilised by vegetation, led to a narrowing of the channel cross-section. Additionally, drifted dense patches of non-rooted floating plants (individually from a few $\mathrm{cm}$ to several $\mathrm{dm}$ in diameter) may have produced plant jams in the shallow parts of active channels (up to $10 \mathrm{~m}$ wide) blocking the water flow locally. The dense vegetation, and especially its rhizomes and roots, stabilised the steep banks of the channels very well (cf. Figs. 16C, D and 19A, B, D).

GLOBAL SAND-DOMINATED ANALOGUES

The upper Narew River is characterized by features that are typical of anastomosing systems such as: a multichannel system with stable and vegetated islands; a strong lithological contrast between in-channel and overbank deposits; a low sinuosity index; a low width/depth ratio; a low longitudinal channel gradient; and a high anabranching index. Similar attributes have been described from other modern anastomosing fluvial systems occurring in temperate humid climatic zones. The following rivers are the best examples: Mistaya, Alexandra, North Saskatchewan, Upper Columbia, Lower Saskatchewan, Ovens, etc. (e.g., Smith, 1976, 1983, 1986; Smith and Smith, 1980; Rust, 1981; Smith et al., 1989; Schumm et al., 1996 Makaske, 1998). Some other features listed below, though not unique, have been described from the Okavango River in Botswana (e.g., McCarthy et al., 1991; McCarthy et al., 1992; Stanistreet et al., 1993; Ellery et al., 1995, 2003; Smith et al., 1997). These features are bedload domination, lack of natural levees, lack of sand ridges and crevasse splays. All those authors noted vegetation to be a crucial element in controlling the development of the anastomosing system, as with the upper Narew River.

\section{DISCUSSION}

This overview of Polish rivers commonly regarded as anastomosing requires some further discussion. The successions described in this paper are not the first for which deposition in an anastomosing river system has been suggested. The role of subsidence in the formation of the anastomosing fluvial pattern in the geological record seems decisive. Moreover, the development of the modern river network, including the Narew River, must be discussed in the context of natural and anthropogenic changes in the Holocene. Finally, the anastomosing river systems described should be compared with each other.

\section{INITIAL AMBIGUITIES IN RESEARCH INTO POLISH} ANASTOMOSING RIVERS

Polish anastomosing rivers were noted in descriptions of the Upper Carboniferous coal-bearing succession of the Upper Silesian Coal Basin in southern Poland (Gradziński et al., 1982: 71). The origin of the Mudstone Series was then attributed partly to meandering and partly to anastomosing rivers. This point of view was repeated in the synthetic facies model showing the depositional environments of the Mudstone Series (Gradziński et al., 2005: fig. 4B; Kędzior et al., 2007: fig. 5).
However, the borehole data, as well as surface and underground direct observations, were not sufficient to conclude which river type the strata actually represented.

The same question appeared during investigations of the mid-Miocene lignites of central Poland. It has not been established whether, at the time of lignite formation, the mires were located in the overbank area of a meandering or an anastomosing system. Simply put, this is due to the lack of exposure of the river channel-fills (e.g., Widera, 2016a; Chomiak et al., 2019; Chomiak, 2020; Widera et al., 2021a, b). Fortunately, these drawbacks do not exist in the case of the anastomosing systems reviewed in this paper.

\section{IMPACT OF SUBSIDENCE ON RIVER PATTERN CHANGE}

Surface subsidence may have been caused by tectonics sensu stricto and/or by compaction in the case of the rivers discussed. Hence, these processes of lowering the land surface, involving parts of river systems, can be defined as tectonic subsidence and compactional subsidence, respectively. In the case of the Triassic anastomosing system (Krasiejów), only tectonic subsidence should be taken into account, as the bedrock is made of lithified rocks such as limestones, dolomites, mudstones and claystones (e.g., Gruszka and Zieliński, 2008; Jewuła et al., 2019), which are subject to limited compaction. However, due to the lack of other data, the influence of tectonics on the anastomosing pattern of the river channels at Krasiejów should be considered in future research.

The geological position of the Neogene river system in the Konin area is different. Firstly, the part of the river system examined in detail is located in a tectonic graben, and secondly, there is a lignite seam below the anastomosing river deposits. Thus, both tectonic and compactional subsidence could have contributed to the reduction of the river slope, and consequently to its anastomosing pattern. Most likely, the tectonics of the deeper substrate prevailed during the accumulation of peat, which then transformed into the lignite seam. In turn, during the development of the Neogene river system above, peat/lignite compaction played a greater role in lowering the depositional surface (e.g., Widera et al., 2019, 2021b; Zieliński and Widera, 2020).

\section{HOLOCENE CHANGES IN RIVER SYSTEMS}

The development of some Holocene river systems is well understood through sedimentological and geomorphological studies, supported by radiocarbon dating and GPR data (e.g., Kozarski and Rotnicki, 1977; Vandenberghe, 1995, 2001; Davies and Sambrook Smith, 2006; Williams et al., 2014; Słowik, 2015). Some of these publications also indicate a significant human influence on changes to the geomorphology of rivers, including their channel patterns. Generally, the river systems described in the papers listed have gone through various stages of development since the last Weichselian glaciation. In all cases, first they were braided (Late Glacial), and then turned into anastomosing or meandering rivers. Along with river channel infill in the Holocene, the velocity of water flow decreased, which created favourable conditions for the development of an anastomosing fluvial system (Candel et al., 2020). In addition, depending on the human influence on the natural processes forming the river, they could transform in the Holocene from anastomosing into meandering (Davies and Sambrook Smith, 2006; Williams et al., 2014) and vice versa (Słowik, 2015).

A similar fluvial development occurred in the modern Polish example of the upper Narew River. Most likely, it was initially a braided fluvial system, which then transformed into a meandering one (Churski, 1973; Banaszuk, 1996). Finally, over time, it 
Comparison of characteristic features and parameters of Polish anastomosing fluvial systems (all data based on publications of the authors' teams devoted to Polish anastomosing rivers)

\begin{tabular}{|c|c|c|c|}
\hline $\begin{array}{l}\text { Feature and/or } \\
\text { parameter }\end{array}$ & Triassic anastomosis & Neogene anastomosis & Quaternary anastomosis \\
\hline Research object & Clay/mud opencast at Krasiejów & $\begin{array}{l}\text { Lignite opencasts, Konin Lignite } \\
\text { Mine }\end{array}$ & Upper Narew River \\
\hline Location & Vicinity of Opole, W Poland & Vicinity of Konin, central Poland & Vicinity of Białystok, NE Poland \\
\hline Age & Late Triassic, Norian & $\begin{array}{l}\text { Late Neogene, upper mid-Miocene } \\
\text { to earliest Pliocene }\end{array}$ & Late Quaternary, Holocene \\
\hline Climate & Hot and dry & $\begin{array}{l}\text { Temperate, from warm humid to } \\
\text { cool dry }\end{array}$ & $\begin{array}{l}\text { Temperate-humid, continental, } \\
\text { with frost in winters }\end{array}$ \\
\hline Channel pattern & $\begin{array}{l}\text { Multi-channel, sometimes } \\
\text { multi-storey }\end{array}$ & Multi-channel, multi-storey & Multi-channel \\
\hline Aspect ratio (w/t) & $w / t=27-60$ & $\begin{array}{c}\mathrm{w} / \mathrm{t}=5-15 \begin{array}{c}(15-30 \text { for secondary } \\
\text { channels })\end{array}\end{array}$ & $w / t=2-10$ \\
\hline Stream power $(\omega)$ & $\omega=1 \mathrm{~W} \cdot \mathrm{m}^{-2}$ & $\omega=2.5-21 \mathrm{~W} \cdot \mathrm{m}^{-2}$ & $\omega=2-3 \mathrm{~W} \cdot \mathrm{m}^{-2}$ \\
\hline Channel deposits & Mud & Sand, sand and mud, mud & Sand \\
\hline Overbank deposits & Clay & Mud (locally clay, silt, lignite) & Peat, sandy peat \\
\hline $\begin{array}{l}\text { Architecture of sedi- } \\
\text { mentary environment }\end{array}$ & $\begin{array}{c}\text { Channels: uniform aggradation from } \\
\text { suspension settling, plane bed, only } \\
\text { small bedforms (current and climb- } \\
\text { ing ripples); } \\
\text { Floodplain: seasonal flood basins, } \\
\text { lack of natural levees and crevasse } \\
\text { splays, common pedogenesis } \\
\text { (vertisols) }\end{array}$ & $\begin{array}{c}\text { Channels: aggradation from both } \\
\text { traction and suspension, plane bed, } \\
\text { small bedforms (ripples) and large } \\
\text { bedforms (dunes), lack of point } \\
\text { bars; } \\
\text { Floodplain: seasonal flood basins, } \\
\text { lack of natural levees and crevasse } \\
\text { splays, present palaeosol horizons } \\
\text { with lignite tops }\end{array}$ & $\begin{array}{c}\text { Channels: limited tractional } \\
\text { aggradation, plane bed, ripples, } \\
\text { uncommon barforms (mainly } \\
\text { mid-channel and linguoid bars); } \\
\text { Floodplain: nearly flat, water- } \\
\text { logged, with dense aquatic vege- } \\
\text { tation (herbaceous), lack of } \\
\text { natural levees and crevasse } \\
\text { splays, numerous small pools }\end{array}$ \\
\hline $\begin{array}{l}\text { Geomorphological } \\
\text { position }\end{array}$ & Flat, broad alluvial plain & $\begin{array}{l}\text { Shallow tectonic graben filled with } \\
\text { lignite seam }\end{array}$ & $\begin{array}{l}\text { Broad valley incised in post-glacial } \\
\text { landscape }\end{array}$ \\
\hline
\end{tabular}

evolved into the present anastomosing fluvial system. However, in the last century and more, this trend has reversed as a result of human activity. Marcinkowski et al. (2017) calculated that in the study area the total length of active river channels (anabranches) has decreased by $>40 \%$ since the beginning of the 20th century.

Among the natural factors that may affect the anastomosing process in areas with temperatures $<0^{\circ} \mathrm{C}$ for several weeks, there are ice jams. They may block fluvial discharge and reduce the river slope, as is the case of the Attawapiskat River in Canada, where the river develops an anastomosing pattern during ice jams (King and Martini, 1984). Ice jams have been taken into account in previous publications (Gradziński et al., 2000, 2003a, b; Marcinkowski et al., 2017). Currently, its significant role in the anastomosing process of the upper Narew River is contradictory, as other rivers in NE Poland and most of the European Lowlands are not multi-channel, anastomosing rivers.

\section{COMPARISON OF ANASTOMOSING SYSTEMS REVIEWED}

The Polish anastomosing fluvial systems reviewed are characterized by both similarities and differences. In general, they all were/are multi-channel and low-energy rivers with variable flows during high water stages. This is particularly noticeable in the case of the Neogene example, where the power of the flood stream reached $21 \mathrm{~W} \cdot \mathrm{m}^{-2}$. However, for most of the time this river, like the Triassic and Holocene examples, was characterized by low-energy flow with stream power $<3 \mathrm{~W} \cdot \mathrm{m}^{-2}$ (Table 5).

The Polish river systems reviewed have more differences than just their age and location. The most important of these concern the differing deposits filling the channels and overbank areas. The channel-fill sediments are sand-dominated in the case of the modern upper Narew River, while in the ancient examples they are from sandy-muddy (Neogene river system in the Konin area) to mud-dominated (Triassic river system at Krasiejów). Similarly, the overbank deposits show textural diversity in these fluvial systems. Overall, the older deposits are more fine-grained (clayey) and contain less organic matter (Table 5).

The aspect ratio $(\mathrm{w} / \mathrm{t})$ values also show the various geometries of the channels. The smallest (2-10) are those for the modern upper Narew River, while the largest (27-60) are those for the Triassic example at Krasiejów. In the case of the Neogene river system from the vicinity of Konin, the mean w/t values are intermediate, that is, in the range of 5-15 (Table 5). Most likely, these differences depended on the susceptibility to erosion of the sediments into which the channels incised (e.g., Gradziński et al., 2000, 2003a, b; Gruszka and Zieliński, 2008; Widera et al., 2019; Zieliński and Widera, 2020).

\section{CONCLUSIONS}

The three reviewed anastomosed fluvial systems from Poland are a significant part of those known from ancient and modern sedimentary environments worldwide. Each evolved at a different time (late Triassic, late Neogene, late Holocene) and under very climatic conditions, that is, from hot semiarid and arid, through semiarid with a cooling trend, to temperate humid (with frost in winters), respectively. This resulted in the deposition of lithologically diverse sediments (both channel and overbank).

The main factor determining the anastomosing fluvial style was tectonics (Triassic and Neogene systems) or progressive filling with sediments (Holocene system), which led to a de- 
crease in the slope of the river valleys. Climate and the mineral content carried by the rivers also affected the stability of the channel banks. For both ancient anastomosing river systems (Krasiejów and Konin), when the climate was dry or semi-dry, their banks were stabilised by the cohesion of fine-grained muddy overbank deposits. By contrast, in a humid climate (upper Narew River), the sandy-peaty riverbanks are stabilised by dense, mainly herbaceous vegetation.

For both the ancient and modern regional (Polish) anastomosing rivers studied, there are analogues woldwide, which developed under similar climatic conditions and resulted in similar sedimentary records. Our review paper contributes to the knowledge about anastomosing rivers, which are still underestimated in the earth-science literature.
Acknowledgements. The authors want to warmly thank everyone who collaborated with them in the last 25 years in the research of Polish anastomosing rivers, that is, the co-authors of their joint publications. We would also like to thank two anonymous reviewers for their efforts to evaluate our paper for Geological Quarterly and A. Wysocka (University of Warsaw) for her editorial help. Furthermore, we are deeply grateful to N. Davies (Cambridge University), G. Nadon (Ohio University), M. Ghinassi (University of Padova) and C.R. Fielding (University of Nebraska) for reading the first version of the manuscript and giving valuable comments. This review paper was financially supported by the National Science Centre, Poland, under research project no. 2017/27/B/ST10/00001.

\section{REFERENCES}

Areń, B., 1964. Geological atlas of Poland: stratigraphic and facies problems. Tertiary, 11/a (in Polish with English summary). Wyd. Geol., Warszawa.

Badura, J., Przybylski, B., 2004. Evolution of the Late Neogene and Eopleistocene fluvial system in the foreland of the Sudetes Mountains, SW Poland. Annales Societatis Geologorum Poloniae, 74: 43-61.

Bałuk, A., 1973. Mapa geologiczna Polski w skali 1:200 000, arkusz Łomża (in Polish). Wyd. Geol., Warszawa.

Banaszuk, H., 1996. Paleogeografia naturalne i antropogeniczne przekształcenia doliny górnej Narwi (in Polish). Wydawnictwo Ekonomia i Środowisko, Białystok.

Bilan, W., 1975. The Rhaetic profile in Krasiejów near Opole (in Polish with English summary). Geologia, 1: 13-19.

Botfalvai, G., Haas, J., Bodor, E.R., Andrea Mindszenty, A., Ősi, A., 2016. Facies architecture and palaeoenvironmental implications of the upper Cretaceous (Santonian) Csehbánya formation at the Iharkút vertebrate locality (Bakony Mountains, Northwestern Hungary). Palaeogeography, Palaeoclimatology, Palaeoecology, 441: 659-678.

Brice, J.C., 1964. Channel pattern and terraces of the Loup River in Nebraska. Geological Survey Professional Paper, 422-D: 1-41.

Bridge, J.S., Jarvis, J., 1982. The dynamics of a river bend: a study in flow and sedimentary processes. Sedimentology, 29 499-541.

Candel, J.H., Makaske, B., Kijm, N., Kleinhans, M.G., Storms, J.E., Wallinga, J., 2020. Self-constraining of low-energy rivers explains low channel mobility and tortuous planforms. The Depositional Record, 6: 648-669.

Carling, P., Jansen, J., Meshkova, L., 2014. Multichannel rivers: their definition and classification. Earth Surface Processes and Landforms, 39: 26-37.

Chimner, R.A., Ewel, K.C., 2005. A tropical freshwater wetland: II. Production, decomposition and peat formation. Wetlands Ecology and Management, 13: 671-684.

Chomiak, L., 2020. Architecture, sedimentology and depositional model for the formation of crevasse splays within a lignite seam at the Tomisławice opencast mine near Konin in central Poland. Geologos, 26: 18-32.

Chomiak, L., Maciaszek, P., Wachocki, R., Widera, M., Zieliński, T., 2019. Seismically-induced soft-sediment deformation in crevasse-splay microdelta deposits (Middle Miocene, central Poland). Geological Quarterly, 63 (1): 162-177.

Churski, T., 1973. Zarys geomorfologii bagiennego odcinka doliny Górnej Narwi (in Polish). Zeszyty Problemowe Postępów Nauk Rolniczych, 134: 11-30.

Ciuk, E., Pożaryska, K., 1982. On paleogeography of the Tertiary of the Polish Lowlands. Prace Muzeum Ziemi, 35: 81-88.
Czapowski, G., Kasiński, J.R., 2002. Facje i warunki depozycji utworów formacji poznańskiej (in Polish). Przegląd Geologiczny, 50: 256-257.

Davies, N.S., Gibling, M.R., 2011. Evolution of fixed-channel alluvial plains in response to Carboniferous vegetation. Nature Geoscience, 4: 629-633.

Davies, N.S., Sambrook Smith, G., 2006. Signatures of Quaternary fluvial response, Upper River Trent, Staffordshire, UK: a synthesis of outcrop, documentary, and GPR data. Zeitschrift für Geomorphologie, 50: 347-374.

Davies, N.S., Shillito, A.P., Slater, B.J., Alexander, G., Liu, A.G., McMahon, W.J., 2020. Evolutionary synchrony of Earth's biosphere and sedimentary-stratigraphic record. Earth-Science Reviews, 201: 102979.

Davies, S.J., Gibling, M.R., 2003. Architecture of coastal and alluvial deposits in an extensional basin: the Carboniferous Joggins Formation of eastern Canada. Sedimentology, 50: 415-439.

Duczmal-Czernikiewicz, A., 2013. Evidence of soils and palaeosols in the Poznań Formation (Neogene, Polish Lowlands). Geological Quarterly, 57 (2): 189-204.

Dyjor, S., 1970. The Poznań series in West Poland (in Polish with English summary). Kwartalnik Geologiczny, 14 (4): 819-835.

Dzik, J., 2003. A breaked herbivorous Archosaur with dinosaur affinities from the early Late Triassic of Poland. Journal of Vertebrate Paleontology, 23: 556-574.

Dzik, J., Sulej, T., 2007. A review of the early Late Triassic Krasiejów biota from Silesia, Poland. Palaeontologia Polonica, 64: 3-27.

Dzik, J., Sulej, T., Kaim, A., Niedźwiedzki, R., 2000. A late Triassic tetrapod graveyard in the Opole Silesia (SW Poland) (in Polish with English summary). Przegląd Geologiczny, 48: 226-235.

Eberth, D.A., Miall, A.D., 1991. Stratigraphy, sedimentology and evolution of a vertebrate-bearing, braided to anastomosed fluvial system, Cutler Formation (Permian-Pennsylvanian), north-central New Mexico. Sedimentary Geology, 72: 225-252.

Ellery, W.N., Ellery, K., Rogers, K.H., McCarthy, T.S., 1995. The role of Cyperus papyrus L. in channel blockage and abandonment in the northeastern Okavango Delta, Botswana. African Journal of Ecology, 33: 25-49.

Ellery, W.N., McCarthy, T.S., Smith, N.D., 2003. Vegetation, hydrology, and sedimentation patterns on the major distributary system of the Okavango Fan, Botswana. Wetlands, 23: 357-375.

Fagan, S.D., Nanson, G.C., 2004. The morphology and formation of floodplain-surface channels, Cooper Creek, Australia. Geomorphology, 60: 107-126. 
Ghibaudo, G., 1992. Subaqueous sediment gravity flow deposits: practical criteria for their field description and classification. Sedimentology, 39: 423-454.

Ghosh, P., Sarkar, S., Maulik, P., 2006. Sedimentology of a muddy alluvial deposit: Triassic Denwa Fm., India. Sedimentary Geology, 191: 3-36.

Gibling, M.R., 2006. Width and thickness of channel bodies and valley fills in the geological record: a literature compilation and classification. Journal of Sedimentary Research, 76: 731-770.

Gibling, M.R., Nanson, G.C., Maroulis, J.C., 1998. Anastomosing river sedimentation in the Channel Country of central Australia. Sedimentology, 45: 595-619.

Gorham, E., Janssens, J.A., Glaser, P.H., 2003. Rates of peat accumulation during the postglacial period in 32 sites from Alaska to Newfoundland, with special emphasis on northern Minnesota. Canadian Journal of Botany, 81: 429-438.

Gradziński, R., Doktor, M., Brzyski, B., 1982. Accumulation of drifted logs and other large plant debris in a Carboniferous fluvial channel at Czerwionka, Upper Silesia. Acta Geologica Polonica, 32: 69-81.

Gradziński, R., Baryła, J., Danowski, W., Doktor, M., Gmur, D., Gradziński, M., Kędzior, A., Paszkowski, M., Soja, R., Zieliński, T., Żurek, S., 2000. Anastomosing system of the upper Narew River, NE Poland. Annales Societatis Geologorum Poloniae, 70: 219-229.

Gradziński, R., Baryła, J., Doktor, M., Gmur, D., Gradziński, M., Kędzior, A., Paszkowski, M., Soja, R., Zieliński, T., Żurek, S. 2003a. Vegetation-controlled modern anastomosing system of the upper Narew River (NE Poland) and its sediments. Sedimentary Geology, 157: 253-276.

Gradziński, R., Baryła, J., Doktor, M., Gmur, D., Gradziński, M., Kędzior, A., Paszkowski, M., Soja, R., Zieliński, T., Żurek, S., 2003b. In-channel accretionary macroforms in the modem anastomosing system of the upper Narew River, NE Poland. Annales Societatis Geologorum Poloniae, 73: 35-53.

Gradziński, R., Doktor, M., Kędzior, A., 2005. Sedimentation of the coal-bearing succession in the Upper Silesia Coal Basin: research trends and current state of knowledge (in Polish with English summary). Przegląd Geologiczny, 53: 734-41.

Gruszka, B., Zieliński, T., 2008. Evidence for a very low-energy fluvial system: a case study from the dinosaur-bearing Upper Triassic rocks of southern Poland. Geological Quarterly, 52 (3): 239-252.

Hill, P.R., Lewis, C.P., Desmaris, S., Kauppaymuthoo, V., Rais, H., 2001. The Mackenzie Delta: sedimentary processes and facies of a high-latitude, fine-grained delta. Sedimentology, $\mathbf{4 8}$ : 1047-1078.

lelpi, A., Gibling, M.R., Bashforth, A.R., Dennar, C.I., 2015. Impact of vegetation on early Pennsylvanian fluvial channels: insight from the Joggins Formation of Atlantic Canada. Journal of Sedimentary Research, 85: 999-1018.

Jewuła, K., Matysik, M., Paszkowski, M., Szulc, J., 2019. The late Triassic development of playa, gilgai floodplain, and fluvial environments from Upper Silesia, southern Poland. Sedimentary Geology, 379: 25-45.

Jones, L.S., Schumm, S.A., 1999. Causes of avulsion: an overview. IAS Special Publication, 28: 171-178.

Kasiński, J.R., Słodkowska, B., 2016. Factors controlling Cenozoic anthracogenesis in the Polish Lowlands. Geological Quarterly, 60 (4): 959-974.

Kemp, J., 2010. Downstream channel changes on a contracting, anabranching river: The Lachlan, southeastern Australia. Geomorphology, 121: 231-244.

Kędzior, A., Gradziński, R., Doktor, M., Gmur, D., 2007. Sedimentary history of a Mississippian to Pennsylvanian coal-bearing succession: an example from the Upper Silesia Coal Basin, Poland. Geological Magazine, 144: 487-496.

King, W.A., Martini, I.P., 1984. Morphology and recent sediments of the lower anastomosing reaches of the Attawapiskat River. Sedimentary Geology, 37: 295-320.

Kowalski, J., Bodzioch, A., Janecki, P.A., Ruciński, M.R., Antczak, M., 2019. Preliminary report on the microvertebrate faunal remains from the Late Triassic locality at Krasiejów, SW Poland. Annales Societatis Geologorum Poloniae, 89: 291-305.

Kozarski, S., Rotnicki, K., 1977. Valley floors and changes of river channel patterns in the North Polish plain during the Late-Würm and Holocene. Quaestiones Geographicae, 4: 51-95.

Kraus, M.J., 2002. Basin-scale changes in floodplain paleosols: implications for interpreting alluvial architecture. Journal of Sedimentary Research, 72: 500-509.

Kraus, M.J., Davies-Vollum, K.S., 2004. Mudrock-dominated fills formed in avulsion splay channels: examples from the Willwood Formation, Wyoming. Sedimentology, 51: 1127-1144.

Latrubesse, E.M., 2015. Large rivers, megafans and other Quaternary avulsive fluvial systems: A potential "who's who" in the geological record. Earth-Science Reviews, 146: 1-30.

Latrubesse, E.M., Franzinelli, E., 2002. The Holocene alluvial plain of the middle Amazon River, Brazil. Geomorphology, 44: 241-257.

Latrubesse, E.M., Franzinelli, E., 2005. The late Quaternary evolution of the Negro River, Amazon, Brazil: implications for island and floodplain formation in large anabranching tropical systems. Geomorphology, 70: 372-397.

Leclair, S.F., Bridge, J.S., 2001. Quantitative interpretation of sedimentary structures formed by river dunes. Journal of Sedimentary Research, 71: 713-716.

Leopold, L.B., Wolman, M.G., 1957. River channel patterns: braided, meandering and straight. United States Geological Survey, Professional Papers, 262B: 39-85.

Lindner, L., Astapowa, S.D., 2000. The age and geological setting of Pleistocene glacigenic beds around the border between Poland and Belarus. Geological Quarterly, 44 (2): 187-197.

McCarthy, T.S., Ellery, W.N., Stanistreet, I.G., 1992. Avulsion mechanisms on the Okavango fan, Botswana: the control of a fluvial system by vegetation. Sedimentology, 39: 779-795.

McCarthy, T.S., Stanistreet, I.G., Cairncross, B., 1991. The sedimentary dynamics of active fluvial channels on the Okavango fan, Botswana. Sedimentology, 38: 471-487.

Maciaszek, P., Chomiak, L., Wachocki, R., Widera, M., 2019. The interpretive significance of ripple-derived sedimentary structures within the late Neogene fluvial succession, central Poland. Geologos, 25: 1-13.

Maciaszek, P., Chomiak, L., Urbański, P., Widera, M., 2020. New insights into the genesis of the "Poznań Clays" - upper Neogene of Poland. Civil and Environmental Engineering Reports, 30 18-32.

Mack, G.H., Leeder, M., Pérez-Arlucea, M., Bailey, B.D.J., 2003. Early Permian silt-bed fluvial sedimentation in the Orogrande basin of the Ancestral Rocky Mts, New Mexico, USA. Sedimentary Geology, 160: 159-178.

Makaske, B., 1998. Anastomosing Rivers: Forms, Processes and Sediments. Koninklijk Nederlands Aardrijkskundig Genootschap, University of Utrecht, Geographical Studies, 249.

Makaske, B., 2001. Anastomosing rivers: a review of their classification, origin and sedimentary products. Earth-Science Reviews, 53: 149-196.

Makaske, B., Lavooi, E., De Haas, T., Kleinhans, M.G., Smith, D.G., 2017. Upstream control of river anastomosis by sediment overloading, upper Columbia River, British Columbia, Canada. Sedimentology, 64: 1488-1510.

Makaske, B., Smith, D.G., Berendsen, H.J.A., De Boer, A.G., Nielen-Kiezebrink, M.F., Locking, T., 2009. Hydraulic and sedimentary processes causing anastomosing morphology of the upper Columbia River, British Columbia, Canada. Geomorphology, 111: 194-205.

McKie, T., Williams, B., 2009. Triassic palaeogeography and fluvial dispersal across the northwest European Basins. Geological Journal, 44: 711-741

Marcinkowski, P., Giełczewski, M., Okruszko, T., 2018. Where might the hands-off protection strategy of anastomosing river lead? A case study of the Narew National Park. Polish Journal of Environmental Studies, 27: 2647-2658.

Marcinkowski, P., Grabowski, R.C., Okruszko, T., 2017. Controls on anastomosis in lowland river systems: Towards pro- 
cess-based solutions to habitat conservation. Science of the Total Environment, 609: 1544-1555.

Martin, A.J., 2000. Flaser and wavy bedding in ephemeral streams: a modern and an ancient example. Sedimentary Geology, 136: $1-5$.

Miall, A.D., 1977. A review of the braided-river depositional environment. Earth-Science Reviews, 13: 1-62.

Nadon, G.C., 1994. The genesis and recognition of anastomosed fluvial deposits: data from the St. Mary River Formation, southwestern Alberta, Canada. Journal of Sedimentary Research, 64 451-463.

Nanson, G.C., 2013. Anabranching and anastomosing rivers. Treatise on Geomorphology, 9: 330-345.

Nanson, G.C., Croke, J.C., 1992. A genetic classification of floodplains. Geomorphology, 4: 459-486.

Nanson, G.C., Knighton, A.D., 1996. Anabranching rivers: their cause, character and classification. Earth Surface Processes and Landforms, 21: 217-239.

Nanson, G.C., Young, R.W., Price, D.M., Rust, B.R., 1988. Stratigraphy, sedimentology and Late Quaternary chronology of the Channel Country of W Queensland. In: Fluvial Geomorphology of Australia (ed. R.F. Warner): 151-175. Academic Press, Sydney.

Nanson, G.C., East, T.J., Roberts, R.G., 1993. Quaternary stratigraphy, geochronology and evolution of the Magela Creek catchment in the monsoon tropics of N Australia. Sedimentary Geology, 83: 277-302.

North, C.P., Nanson, G.C., Fagan, S.D., 2007. Recognition of the sedimentary architecture of dryland anabranching (anastomosing) rivers. Journal of Sedimentary Research, 77 925-938.

Okruszko, H., Oświt, J., 1973. Przyrodnicza charakterystyka bagiennej doliny Górnej Narwi jako podstawa melioracji (in Polish). Zeszyty Problemowe Postępów Nauk Rolniczych, 134 31-99.

Passega, R., 1977. Significance of CM diagrams of sediments deposited by suspension. Sedimentology, 24: 723-733.

Phillips, J.D., 2014. Anastomosing channels in the lower Neches River valley, Texas. Earth Surface Processes and Landforms, 39: 1888-1899.

Piwocki, M., Ziembińska-Tworzydło, M., 1997. Neogene of the Polish Lowlands - lithostratigraphy and pollen-spore zones. Geological Quarterly, 41 (1): 21-40.

Piwocki, M., Badura, J., Przybylski, B., 2004. Neogen. In: Peryt T.M, Piwocki M. (red.). Budowa geologiczna Polski, t. 1 , Stratigrafia część 3a, Kenozoik - paleogen, neogen (in Polish) 71-133. Polish Geological Institute, Warszawa.

Reddy, P.H., Prasad K.R., 1988. Paleocurrent and paleohydrologic analysis of Barakar and Kamthi Formations in the Manuguru coalfield, Andhra Pradesh, India. Indian Journal of Earth Sciences, 15: 34-44

Rees, A.I., 1966. Some flume experiments with a fine silt. Sedimentology, 6: 209-240.

Reineck, H.E., Singh, I.B., 1980. Depositional Sedimentary Environments. Springer-Verlag, Berlin.

Rust, B.R., 1981. Sedimentation in an arid-zone anastomosing fluvial system: Cooper's Creek, Central Australia. Journal of Sedimentary Petrology, 51: 745-755

Rust, B.R., Nanson, G.C., 1986. Contemporary and palaeochanne patterns and the Late Quaternary stratigraphy of Cooper Creek, SW Queensland, Australia. Earth Surface Processes and Landforms, 11: 581-590.

Rust, B.R., Gibling, M.R., Legun, A.S., 1984. Coal deposition in an anastomosing-fluvial system: the Pennsylvanian Cumberland Group south of Joggins, Nova Scotia, Canada. IAS Special Publication, 7: 105-120.

Schumm, S.A., 1968. Speculations concerning paleohydraulic controls on terrestrial sedimentation. GSA Bulletin, 79: 1573-1588.

Schumm, S.A., 1972. Fluvial paleochannels. SEPM Special Publication, 16: 98-107.
Schumm, S.A., Erskine, W.D., Tilleard, J.W., 1996. Morphology, hydrology, and evolution of the anastomosing Ovens and King Rivers, Victoria, Australia. GSA Bulletin, 108: 1212-1224.

Schumann, R.R., 1989. Morphology of Red Creek, Wyoming, an arid-region anastomosing channel system. Earth Surface Processes and Landforms, 14: 277-288.

Shepard, F.P., 1954. Nomenclature based on sand-silt-clay ratios. Journal of Sedimentary Research, 24: 151-158.

Simon, S.S.T., Gibling, M.R., 2017. Fine-grained meandering systems of the Lower Permian Clear Fork Fm. of north-central Texas: Lateral and oblique accretion on an arid plain. Sedimentology, 64: 714-746.

Słodkowska, B., Kasiński, J.R., 2016. Paleogene and Neogene: a time of dynamic changes of climate (in Polish with English summary). Przegląd Geologiczny, 64: 15-25.

Słodkowska, B., Widera, M., 2021. Vegetation response to environmental changes based on palynological research on the Middle Miocene lignite at the Jóźwin IIB open-cast mine (Konin region, central Poland). Annales Societatis Geologorum Poloniae, 91: 149-166.

Słowik, M., 2015. Is history of rivers important in restoration projects? The example of human impact on a lowland river valley (the Obra River, Poland). Geomorphology, 251: 50-63.

Smith, D.G., 1976. Effect of vegetation on lateral migration of anastomosed channels of a glacier meltwater river. GSA Bulletin, 87: 857-860.

Smith, D.G., 1983. Anastomosed fluvial deposits: modern examples from Western Canada. IAS Special Publication, 6 155-168.

Smith, D.G., 1986. Anastomosing river deposits, sedimentation rates and basin subsidence, Magdalena River, northwestern Colombia, South America. Sedimentary. Geology, 46: 177-196.

Smith, D.G., Smith, N.D., 1980. Sedimentation in anastomosed river systems: examples from alluvial valleys near Banff, Alberta. Journal of Sedimentary Petrology, 50: 157-164.

Smith, N.D., Cross, T.A., Dufficy, J., Clough, S.R., 1989. Anatomy of avulsion. Sedimentology, 36: 1-23.

Smith, N.D., McCarthy, T.S., Ellery, W.N., Merry, C.L., Rüther, H., 1997. Avulsion and anastomosis in the panhandle region of the Okavango Fan, Botsvana. Geomorphology, 20: 49-65.

Stanistreet, I.G., Cairncross, B., McCarthy, T.S., 1993. Low sinuosity and meandering bedload rivers of the Okavango Fan channel confinement by vegetated levees without fine sediment. Sedimentary Geology, 85: 135-156.

Szulc, J., 2005. Sedimentary environments of the vertebrate-bearing Norian deposits from Krasiejów, Upper Silesia, Poland. Hallesches Jahrbuch für Geowisschenschaften, B19: 161-170.

Szulc, J., Racki, G., 2015. Grabowa Formation - the basic lithostratigraphic unit of the Upper Silesian Keuper (in Polish with English summary). Przegląd Geologiczny, 63: 103-113.

Szulc, J., Racki, G., Jewuła, K., 2015. Key aspects of the stratigraphy of the Upper Silesian middle Keuper, southern Poland. Annales Societatis Geologorum Poloniae, 85: 557-586.

Środoń, J., Szulc, J., Anczkiewicz, A., Jewuła, K., Banaś, M., Marynowski, L., 2014. Weathering, sedimentary, and diagenetic controls of mineral and geochemical characteristics of the vertebrate-bearing Silesian Keuper. Clay Minerals, 49 : 569-594.

Therrien, F., Fastovsky, D.E., 2000. Paleoenvironments of early theropods, Chinle Fm. (Late Triassic), Petrified Forest National Park, Arizona. Palaios, 15: 194-211.

Tooth, S., 2000. Process, form and change in dryland rivers; a review of recent research. Earth-Science Reviews, 51: 67-107.

Twidale, C.R., 2004. River patterns and their meaning. Earth-Science Reviews, 67: 159-218.

Uba, C.E., Heubeck, C., Hulka, C., 2005. Facies analysis and basin architecture of the Neogene Subandean synorogenic wedge, southern Bolivia. Sedimentary Geology, 180: 91-123.

Urbański, P., Widera, M., 2016. Geology of lignite deposits in the south-western Wielkopolska region (in Polish with English summary). Przegląd Geologiczny, 64: 791-798. 
Utescher, T., Mosbrugger, V., Ashraf, A.R., 2000. Terrestrial climate evolution in northwest Germany over the last 25 Million years. Palaios, 15: 430-449.

Vandenberghe, J., 1995. Timescales, climate and river development. Quaternary Science Reviews, 14: 631-638.

Vandenberghe, J., 2001. A typology of Pleistocene cold-based rivers. Quaternary International, 79: 111-121.

Widera, M., 2007. Lithostratigraphy and palaeotectonics of the sub-Pleistocene Cenozoic of Wielkopolska (in Polish with English summary). Adam Mickiewicz University Press, Poznań.

Widera, M., 2012. Fluvial origin of the Wielkopolska Member based on data from the central Poland (in Polish with English summary). Górnictwo Odkrywkowe, 53: 109-118.

Widera, M., 2013. Sand- and mud-filled fluvial palaeochannels in the Wielkopolska Member of the Neogene Poznań Formation, central Poland. Annales Societatis Geologorum Poloniae, 83 19-28.

Widera, M., 2016a. Depositional environments of overbank sedimentation in the lignite-bearing Grey Clays Member: new evidence from Middle Miocene deposits of central Poland. Sedimentary Geology, 335: 150-165.

Widera, M., 2016b. Genetic classification of Polish lignite deposits: A review. International Journal of Coal Geology, 158: 107-118.

Widera, M., 2021. Geologia polskich złóż węgla brunatnego (in Polish). Bogucki Wydawnictwo Naukowe, Poznań

Widera, M., Kowalska, E., Fortuna, M., 2017. A Miocene anastomosing river system in the area of Konin Lignite Mine, central Poland. Annales Societatis Geologorum Poloniae, 87: 157-168.

Widera, M., Chomiak, L., Zieliński, T., 2019. Sedimentary facies, processes and paleochannel pattern of an anastomosing river system: an example from the Upper Neogene of Central Poland. Journal of Sedimentary Research, 89: 487-507.

Widera, M., Zieliński, T., Chomiak, L., Maciaszek, P., Wachocki, R., Bechtel, A., Słodkowska, B., Worobiec, E., Worobiec, G. 2021a. Tectonic-climatic interactions during changes of depositional environments in the Carpathian foreland: An example from the Neogene of central Poland. Acta Geologica Polonica, 71: 519-541.

Widera, M., Bechtel, A., Chomiak, L., Maciaszek, P., Słodkowska, B., Wachocki, R., Worobiec, E., Worobiec, G., Zieliński, T., 2021b. Palaeoenvironmental reconstruction of the Konin Basin (central Poland) during lignite accumulation linked to the Mid-Miocene Climate Optimum. Palaeogeography, Palaeoclimatology, Palaeoecology, 568: 110307.

Williams, M., Zalasiewicz, J., Davies, N.S. Mazzini, I., Goiran, J.-P., Kane, S., 2014. Humans as the third evolutionary stage of biosphere engineering of rivers. Anthropocene, 7: 57-63.

Wyrwicki, R., Wiewióra, A., 1981. Clay minerals of the Upper Miocene sediments in Poland. Bulletin Polish Academy of Science, Earth Sciences, 29: 67-71.

Zachos, J., Pagani, M., Sloan, L., Thomas, E., Billups, K., 2001 Trends, rhythms, and aberrations in global climate $65 \mathrm{Ma}$ to present. Science, 292: 686-693.

Ziegler, P.A., 1982. Geological Atlas of Western and Central Europe. Shell International Petroleum Maatschappij, B.V.

Zieliński, T., 2014. Sedymentologia. Osady rzek i jezior (in Polish). Adam Mickiewicz University Press, Poznań.

Zieliński, T., Widera, M., 2020. Anastomosing-to-meandering transitional river in sedimentary record: a case study from the Neogene of central Poland. Sedimentary Geology, 404: 105677. 